\title{
Tibet's minority languages: Diversity and endangerment
}

\author{
Short title: Tibet's minority languages \\ Authors: GERALD ROCHE (Asia Institute, University of Melbourne, \\ g.roche@unimelb.edu.au) \\ HIROYUKI SUZUKI (IKOS, University of Oslo, hiroyuki.suzuki@ikos.uio.no)
}

\begin{abstract}
Asia is the world's most linguistically diverse continent, and its diversity largely conforms to established global patterns that correlate linguistic diversity with biodiversity, latitude, and topography. However, one Asian region stands out as an anomaly in these patterns - Tibet, which is often portrayed as linguistically homogenous. A growing body of research now suggests that Tibet is linguistically diverse. In this article, we examine this literature in an attempt to quantify Tibet's linguistic diversity. We focus on the minority languages of Tibet-languages that are neither Chinese nor Tibetan. We provide five different estimates of how many minority languages are spoken in Tibet. We also interrogate these sources for clues about language endangerment among Tibet's minority languages, and propose a sociolinguistic categorization of Tibet's minority languages that enables broad patterns of language endangerment to be perceived. Appendices include lists of the languages identified in each of our five estimates, along with references to key sources on each language. Our survey found that as many as 60 minority languages may be spoken in Tibet, and that the majority of these languages are endangered to some degree. We hope out contribution inspires further research into the predicament of Tibet's minority languages, and helps support community efforts to maintain and revitalize these languages.
\end{abstract}

NB: This is the accepted version of this article, which was published in Modern Asian Studies in April 2018. https://doi.org/10.1017/S0026749X1600072X

\footnotetext{
* The authors wish to thank Juha Janhunen, Nicolas Tournadre, and Katia Chirkova for their valuable feedback. Any remaining errors or omissions are our own responsibility. Gerald Roche acknowledges the support of the Australian Research Council for his Discovery Early Career Research Award project "Ethnicity and Assimilation in China: The Monguor of Tibet." Hiroyuki Suzuki would like to thank the Japan Society for the Promotion of Science for the support of his research entitled "Study on the Dialectal Development of Tibetan Spoken in Yunnan, China, through a Description of the Linguistic Diversity" (Grant No. 25770167).
} 


\section{Introduction: Linguistic diversity in Asia, China, and Tibet}

Asia is the world's most linguistically diverse continent, containing about a third of the languages spoken on earth today. ${ }^{1} \mathrm{~A}$ recent investigation of global linguistic diversity found that per area, Asia (including the Pacific) has three times as many languages as Europe and America combined. ${ }^{2}$ Beyond the number and density of languages spoken in Asia, the region is also home to almost a third of global language hotspots - areas that contain assemblages of languages that are both diverse and endangered. ${ }^{3}$ Asia, therefore, plays a key role in harbouring global linguistic diversity. In this article, we argue that the Tibetan regions of China (hereafter, 'Tibet') form a significant yet underexplored aspect of this diversity.

The distribution of linguistic diversity in Asia generally follows global patterns. More languages are spoken in lower latitudes, and relatively fewer at higher latitudes. ${ }^{4}$ Linguistic diversity in Asia also typically correlates with biological diversity, as observed at the global scale. ${ }^{5}$ Furthermore, rugged mountainous regions, such as the Himalayas and the Southeast Asian Massif, harbour more languages than 'smooth' lowland terrain. ${ }^{6}$

${ }^{1}$ Asia is home to 2,301 languages, accounting for 32.4 per cent of the world's 7,102 languages, M. Paul Lewis, Gary F. Simons, and Charles D. Fennig (eds). Ethnologue: Languages of the world, Eighteenth edition, SIL International, Dallas, 2015. Online version: http://www.ethnologue.com, accessed 13 October 2015.

2 Jaceb Bock Axelsen and Susanna Manrubia. 'River density and landscape roughness are universal determinants of linguistic diversity', Proceedings of the royal society B vol. 281, 2014, 20133029, http://dx.doi.org/10.1098/rspb.2013.3029, accessed 12 December 2015.

${ }^{3}$ Asia contains five (27.7 per cent) of the eighteen global language hotspots. Language hotspots are defined on the basis of three criteria: language diversity (calculated on the basis of languages across families), degree of endangerment, and extent of documentation. Gregory D. S. Anderson, 'Language hotspots: What (applied) linguistics and education should do about language endangerment in the twenty-first century'. Language and education, vol. 25, no. 4, 2011, pp. 273-289.

${ }^{4}$ Ruth Mace and Mark Pagel, 'A latitudinal gradient in the density of human languages in North America', Proceedings of the royal society of London B: Biological sciences, vol. 261, no. 1360, 1995, pp. 117-121; Daniel Nettle, 'Language diversity in West Africa: An ecological approach', Journal of anthropological archaeology vol. 15, no. 4, 1996, pp. 403-438; Daniel Nettle, 'Explaining global patterns of language diversity', Journal of anthropological archaeology, vol. 17, no. 4, 1998, pp. 354-374; Daniel Nettle, 'Ecological influences on human behavioural diversity: a review of recent findings', Trends in ecology and evolution vol. 24, no.11, 2009, pp. 618-624; Elizabeth Cashdan, 'Ethnic diversity and its environmental determinants: Effects of climate, pathogens, and habitat diversity', American anthropologist, vol. 103, no.4, 2001, pp. 968-991.

5 Jonathan Loh and David Harmon, 'A global index of biocultural diversity', Ecological indicators, vol. 5, no.3, 2005, pp. 231-241; Luisa Maffi, 'Linguistic, cultural, and biological diversity', Annual review of anthropology, vol. 34, 2005, pp. 599-617; Larry J. Gorenflo, Suzanne Romaine, Russell Mittermeier, and Kristen Walker-Painemilla, 'Co-occurrence of linguistic and biological diversity in biodiversity hotspots and high biodiversity wilderness areas', Proceedings of the national academy of sciences, vol. 109, no.21, 2012, pp. 8032-8037; Catherine Grant, 'Analogies and links between cultural and biological diversity', Journal of cultural heritage management and sustainable development, vol. 2, no.2, 2012, pp. 153-163.

6 John Richard Stepp, Hector Castaneda, and Sarah Cervone, 'Mountains and biocultural diversity', Mountain research and development, vol. 25, no. 3, 2005, pp. 223-227; Mark Turin, 'A multitude of 
China, with 297 languages - more than all of Europe-contains approximately 13 per cent of Asia's languages. ${ }^{7}$ Again, this diversity broadly follows global patterns, with higher diversity in the southern, tropical regions than in the north, and higher diversity in biodiverse mountainous areas (see Figure 1). In this regards, we can contrast the 155 languages spoken in Yunnan Province (one for about every 300,00 people) with the mere eight (one for every 4.7 million people) that are spoken in the north-eastern province of Heilongjiang, which is 13 per cent larger than Yunnan but has approximately eight million fewer people.

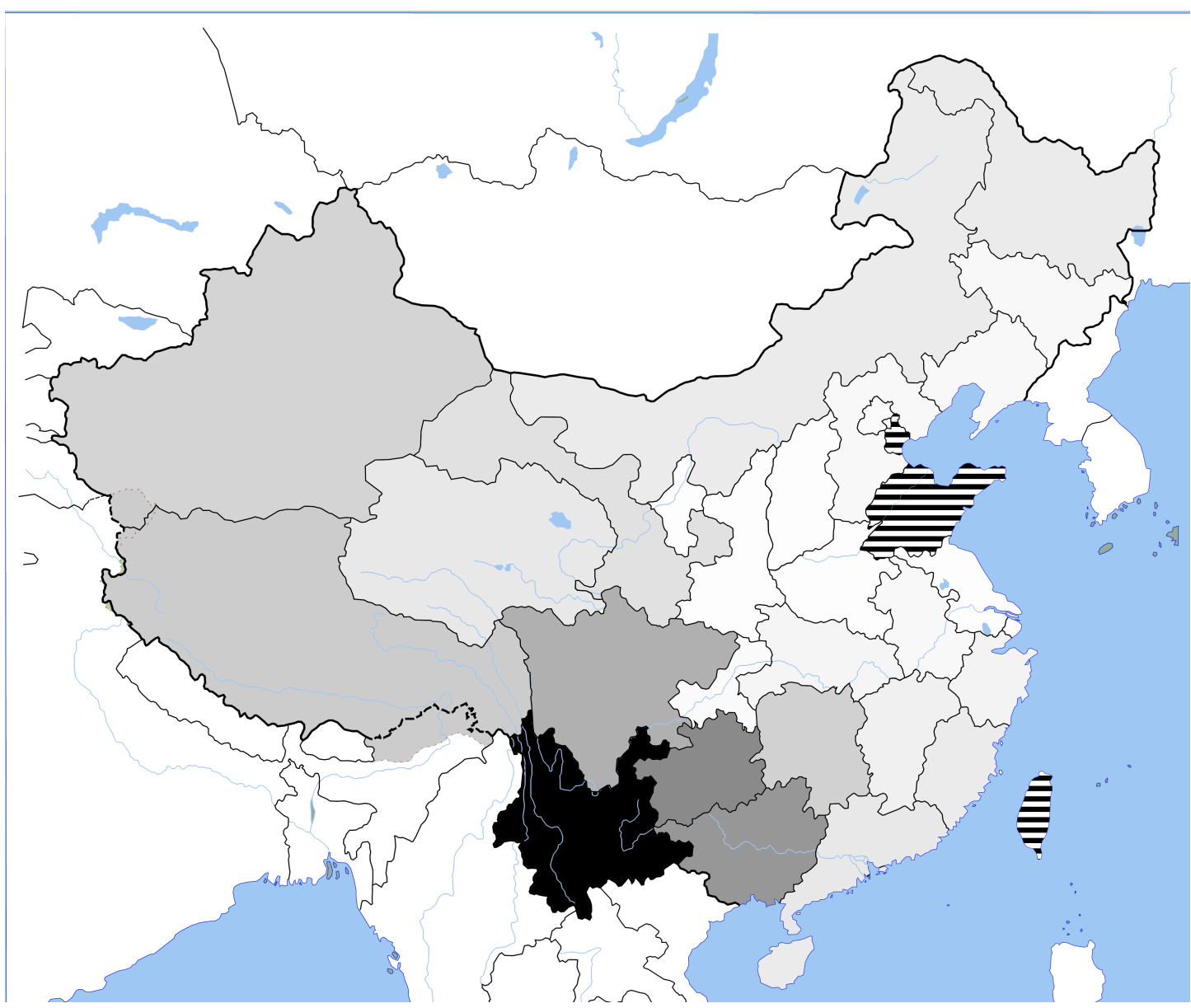

Figure 1. Language density in China. Shading signifies the number of languages spoken in a province, with darker provinces having more languages. See Appendix 1 for underlying data.

In light of these patterns and their applicability to Asia in general, and China specifically, Tibet is an anomaly. A common misconception, in both popular and academic representations, is that Tibet is linguistically homogenous. And yet, both global and national patterns of linguistic diversity suggest that Tibet should display some extent of linguistic diversity, due to its low latitude (in the subtropics), rugged

mountain voices', Sustainable mountain development, vol. 52, 2007, pp. 11-13; Axelsen and Manrubia, 'River density and landscape roughness'.

${ }^{7}$ Lewis et al, Ethnologue. 
terrain, and high biodiversity (particularly in the south and east). In fact, recent linguistic research is bearing out Tibet's conformity to these expectations. ${ }^{8}$

Like linguistic diversity everywhere, linguistic diversity in Asia is decreasing, and, therefore, Asia's role as a bastion of global linguistic diversity appears to be under threat. ${ }^{9}$ In studies on the causes of declining linguistic diversity, one of the most robust correlations is the negative relationship between economic development and linguistic diversity. ${ }^{10}$ Given the pace of economic development across Asia, particularly in China, this suggests that the region stands on the brink of large-scale language loss. One study, looking at global patterns of language diversity, applied the correlation between development and language loss from the USA at a global scale, and found 'a global drop in LD [linguistic diversity] expected overall', with half of the world's languages becoming extinct if Africa and Asia reach the economic development levels of the Americas. ${ }^{11}$ Current trends in China seem to fit this grim prediction. Two studies estimate that approximately 50 per cent of China's languages are endangered to varying degrees, ${ }^{12}$ while a Chinese expert on language endangerment, $\mathrm{Xu}$ Shixuan, ${ }^{13}$ has stated that 'marginalized languages, threatened by

\footnotetext{
${ }^{8}$ Nicolas Tournadre, 'Arguments against the concept of 'conjunct' / 'disjunct' in Tibetan' in Chomolangma, Demawend und Kasbek, Festschrift für Roland Bielmeier zu seinem 65 Geburtstag, Brigitte Huber, Marianne Volkart, Paul Widmer, and Peter Schwieger (eds), International Institute for Tibetan and Buddhist Studies GmbH, Halle, 2008, pp. 281-308; Nicolas Tournadre, 'The Tibetic languages and their classification', in Trans-Himalayan linguistics: Historical and descriptive linguistics of the Himalayan area, Thomas Owen-Smith and Nathan W. Hill (eds), Walter de Gruyter, Berlin, 2014, pp. 105-129; Hiroyuki Suzuki, 'Introduction to the method of the Tibetan linguistic geography - a case study in the Ethnic Corridor of West Sichuan' in Linguistic substratum in Tibet New perspective towards historical methodology (No. 16102001) report, Yasuhiko Nagano (ed), National Museum of Ethnology, Suita, 2009, pp. 15-34; Hiroyuki Suzuki, 'Brief introduction to the endangerment of Tibetic languages: special reference to the language situation in Eastern Tibetan cultural area', The journal of linguistic studies, vol. 19, no. 3, 2014, pp. 281-301; Gerald Roche, 'The vitality of Tibet's minority languages in the twenty-first century: Preliminary remarks', Multiethnica, 35, 2014, pp. 24-31; Gerald Roche, 'The transformation of Tibet's language ecology in the twentyfirst century', International journal of the sociology of language, vol. 245, 2017 (in press).

${ }^{9}$ Peter Austin and Julia Sallabank, The Cambridge handbook of endangered languages. Cambridge University Press, Cambridge, 2015; David Crystal, Language death, Cambridge University Press, Cambridge, 2000; Nancy Dorian, Small language fates and prospects: Lessons of persistence and change from endangered languages, Brill, Leiden, 2014; Nicholas Evans, Dying words: Endangered languages and what they have to tell us, John Wiley and Sons, New York, 2011.

$10 \mathrm{John}$ Wendel and Patrick Heinrich. 'A framework for language endangerment dynamics: the effects of contact and social change on language ecologies and language diversity', International journal of the sociology of language, vol. 218, 2012, pp. 145-166; Tatsuya Amano, Brody Sandel, Heidi Eager, Edouard Bulteau, Jens-Christian Svenning, Bo Dalsgaard, Carsten Rahbek, Richard G. Davies, and William J. Sutherland. 'Global distribution and drivers of language extinction risk', Proceedings of the royal society of London B: Biological sciences vol. 281, no. 1793, 2014, 20141574, http://dx.doi.org/10.1098/rspb.2014.1574, accessed 12 December 2015.

${ }^{11}$ Axelsen and Manrubia, 'River density and landscape roughness', p. 6.

${ }^{12}$ Christopher Moseley (ed) Atlas of the world's languages in danger 3rd edition, UNESCO, Paris, 2010. Online edition: http://www.unesco.org/languages-atlas/, accessed 13 October 2015; Lewis et al, Ethnologue.

${ }^{13} \mathrm{Xu}$ Shixuan, 'Language Endangerment', in The language situation in China, Li Yuming and Li Wei (eds), vol. 1, De Gruyter, Berlin/ Boston, 2003, p. 269.
} 
the dominant language(s) in the area [are] gradually dying off' with the result being that 'the number of speakers of half of China's languages are decreasing.'

Exactly how this broad pattern of endangerment is reflected in Tibet is less clear. Tibet is mostly represented as linguistically homogenous ${ }^{14}$ - a view we contest, in light of both recent research and the broad patterns of linguistic diversity mentioned above. These articles tend to focus on the social and political relations between the Tibetan and Chinese languages, characterized as one of unequal relations between a dominant majority and marginalized minority. These authors characterize the situation as being pervaded with an anxiety that Posner has described as typical of minority-language speakers everywhere-'the overwhelming fear [that] bilingualism and consequently diglossia are merely steps towards language shift, attrition, and even "death." 15 And although these articles are unanimous in declaring the Tibetan language threatened, none provide any systematic description of the sociolinguistic situation within any of the numerous language vitality frameworks available. Furthermore, they tell us nothing about linguistic diversity in the region or how it is threatened.

Given this situation, we take as our focus the 'minority languages' of Tibet, i.e., languages that are spoken in Tibet but are neither Tibetan nor Chinese. Our article has two aims in regards to these languages. The first is to enumerate Tibet's minority languages, and thus examine the extent to which the region conforms to global patterns governing the distribution of linguistic diversity. Our second aim is to examine what is known about the vitality of these languages, and once again to understand if the regions' languages fit the patterns observed at the global and national levels. The first sections of the article concentrate on establishing important definitions which frame the following discussion: how languages are defined, how we define Tibet, and how we define its minority languages. Following this, we describe three broad sociolinguistic categories that enable us to generalize about the vitality of Tibet's minority languages in the absence of detailed information on most of the individual languages. Finally, we provide several different estimates on how many minority languages are spoken in Tibet, based on different sources, and discuss what each estimate tells us about patterns of endangerment in the region. Our aim in doing so is to position Tibet's minority languages within broader patterns of endangerment,

\footnotetext{
${ }^{14}$ Nicolas Tournadre, 'The dynamics of Tibetan-Chinese bilingualism: The current situation and future prospects' China perspectives, vol. 45, 2003, pp. 1-9, http://chinaperspectives.revues.org/231, accessed 12 December 2015; Fernand de Varennes, 'Language rights and Tibetans in China: A look at international law' in Minority languages in today's global society, Kunsang Gya, Andrea Snavely and Elliot Sperling (eds), Trace Foundation, New York, 2012, pp. 14-61; Kalsang Yeshe, 'A preliminary note on Chinese codeswitching in modern Lhasa Tibetan' in Tibetan modernities: Notes from the field on cultural and social change, Robert Barnett and Ronald David Schwartz (eds), Brill, Leiden, 2012, pp. 213-48; Françoise Robin, 'Streets, slogans and screens: New paradigms for the defence of the Tibetan language', in On the fringes of the harmonious society: Tibetans and Uyghurs in socialist China, Trine Brox and Ildikó Bellér-Hann (eds), NIAS Press, Copenhagen, 2014, pp. 209-234; Lama $\mathrm{Jabb}$, Oral and literary continuities in modern Tibetan literature: The inescapable nation, Lexington Books, New York, 2015.

${ }^{15}$ Rebecca Posner, 'Language conflict in Romance: Decline, death, and survival', in Bilingualism and language conflict in Romance, Rebecca Posner and John Green (eds), Mouton de Gruyter, Berlin and New York, 1993, p. 45.
} 
shift, and extinction that are occurring throughout Asia, giving rise to one of the most significant developments in global linguistic diversity taking place today. We begin our discussion below by examining some of the issues related to identifying and counting languages.

\section{Defining and counting languages}

Languages cannot be unambiguously distinguished from one another, nor languages from dialects - different combinations of linguistic, social, historical, and cultural criteria give radically different results. It is therefore crucial to understand the various criteria that are used to differentiate languages and how they are applied. In this section, we therefore outline some of the most common methods of linguistic differentiation employed in our sources, and by linguists more generally: mutual intelligibility, comparative linguistics, and geolinguistics. We also discuss the implications and limitations of these methods, and engage with critical perspectives on such practices.

Perhaps the most commonly applied linguistic criteria for differentiating languages is mutual intelligibility. ${ }^{16}$ Intelligibility tests are ideally administered to 'ideal speakers' who rarely communicate with people beyond their speech community, and languages differentiated on the capacity of these ideal speakers to comprehend one another. However, mutual intelligibility is seldom an absolute criterion for distinguishing languages. ${ }^{17}$ For instance, languages like Malay and Indonesian are considered separate languages despite their intelligibility, as are Norwegian and Swedish. Such languages, which have been deliberately differentiated from each other despite their intelligibility, are termed ausbau languages, or languages by development. ${ }^{18}$ Nonetheless, intelligibility is still often used as the sole criteria for differentiating languages, including in many of the sources we consulted for this study.

Comparative linguistic analysis is another commonly used method for differentiating languages. This involves comparison of the sound systems and wordforms of linguistic varieties, including lexicostatistic methods, which quantitatively examine the degree of lexical cognates shared by varieties. According to this methodology, phonological correspondence or lexical similarity allows us to treat close varieties as a single language, regardless of their intelligibility. ${ }^{19}$ However, this approach faces difficulties in areas where languages are in intense contact, where it often fails to distinguish between borrowing and descent. For example, even though

\footnotetext{
${ }^{16}$ Clare F. O'Leary, 'The role of recorded text tests in intelligibility assessment and language program decisions', Notes on sociolinguistics, Special Issue 2, 1994, pp. 48-72; Angela Kluge, 'RTT retelling method: an alternative approach to intelligibility testing', SIL Electronic Working Papers, 2007-006, 2007, http://www.sil.org/silewp/2007/silewp2007-006.pdf, accessed 12 December 2015.

17 Jeff Siegel, Second dialect acquisition, Cambridge University Press, Cambridge, 2010, p. 1.

18 Heinz Kloss, "“Abstand Languages" and "Ausbau Languages", Anthropological linguistics, vol. 9, no.7, 1967, pp. 29-41.

${ }^{19}$ Sun Hongkai 孙宏开, 'Lun Shixingyu de neibu chayi --- Jianlun yuyan shibie de tongjiedu fangfa 论史兴语的内部差异---兼论语言识别的通解度方法', Minzu yuwen 民族语文, vol. 2, 2013, pp. $21-30$.
} 
the lexicon of Japanese, Korean, and Vietnamese are between 70 and 80 per cent Sinitic, these are most certainly not Sinitic languages, ${ }^{20}$ and while over half of the vocabulary of English is non-Germanic, it remains a Germanic language.

Languages can also be differentiated by geolinguistic analysis. ${ }^{21}$ This involves drawing isoglosses on linguistic maps, showing the distribution of linguistic features, and their spatial clustering as varieties. Geolinguistic analysis can also be used to measure the extent of linguistic difference between varieties, and also enables us to identify on-going language changes. However, extralinguistic factors, such as migration history, urbanization, and changes of the social environment, should also be considered.

The practice of identifying languages using these sorts of linguistic criteria has been criticized. One criticism is that while such practices construe languages as 'things' which are natural, distinct, stable, 'bounded, closed, and geographically fixed', ${ }^{22}$ they are more accurately and fruitfully viewed as inventions or social constructions that are constantly being redefined-as processes rather than objects. ${ }^{23}$ In this view, identifying and enumerating languages is not a descriptive process, but rather a creative one. Moreover, it has been argued that such practices have a distinctly colonial politic, 'heavily influenced by an ideology of racial and national essences'. ${ }^{24}$ Such essentializing, normative metalinguistic discourses are seen to have numerous negative outcomes. For example, it has been pointed out that such definitions of language can contribute to inter-language competition, which in turn contributes to language endangerment. ${ }^{25}$

Such classificatory practices also often contradict the understandings and perceptions of the communities being studied, ${ }^{26}$ amounting to a form of 'epistemic

${ }^{20}$ Sun Hongkai 孙宏开, 'Baimayu shi Zangyu de yige fangyan huo tuhua ma? 白 $\square$ 语是藏语的一 个方言或土话吗?', Yuyan kexue 语言科学 vol. 1, 2003, pp. 65-75.

21 Oskar Bandle. Studien zur westnordischen Sprachgeographie: Haustierterminologie im Norwegischen, Isländischen und Färöischen, Munksgaard, København, 1967; Takesi Sibata 柴田武, Gengotirigaku no hoohoo 言語地理学の方法, Tikuma Syoboo, Tokyo, 1969; Ray Iwata 岩田礼 (ed), Hanyu fangyan jieshi ditu 汉语方言解释地图, Hakuteisya, Tokyo, 2009.

${ }^{22}$ Robert E.Moore, Sari Pietikäinen, and Jan Blommaert, 'Counting the losses: Numbers as the language of language endangerment', Sociolinguistic studies, vol. 4, no. 1, 2010, pp. 1-26.

23 Sinfree Makoni and Alastair Pennycook (eds), Disinventing and reconstituting languages. Multilingual Matters, Bristol, 2007.

24 Judith Irvine and Susan Gal, 'Language ideology and language differentiation', in Regimes of language: Ideologies, polities, and identities, Paul Kroskrity (ed), School of American Research Press, Sante Fe, 2000, p. 46.

${ }^{25}$ Lise M.Dobrin, Peter K. Austin, and David Nathan, 'Dying to be counted: the commodification of endangered languages in documentary linguistics', Proceedings of the conference on language documentation and linguistic theory. School of Oriental and African Studies, London, 2007, http://www.dnathan.com/eprints/dnathan_etal_2007_commodification.pdf, accessed 17 August 2016.

${ }^{26}$ Peter Mülhäusler, 'Naming languages, drawing language boundaries, and maintaining languages, with special reference to the linguistic situation in Papua New Guinea', in Language diversity in the Pacific: Endangerment and survival, Dennis Cunningham, D. E. Ingram and Kenneth Sumbuk (eds), Multilingual Matters, Clevedon, pp. 24-39, 2006. 
violence' ${ }^{27}$ This is at least partially true for the present case. In the national Chinese context, languages are defined and supported by the state on the basis of their writing systems; since languages are written, spoken varieties are dialects by default. ${ }^{28} \mathrm{~A}$ similar situation prevails in Tibetan 'folk linguistics', where a distinction between $y i$ ge 'writing' and skad 'spoken languages' is maintained. And although distinct terms for language and dialect exist (skad rigs and yul skad), individual languages are typically named in such a way that obscures this distinction, usually by appending skad to a place or people, to indicate the speech variety, rather than the language, of a place or people. We therefore find bod skad for the speech of any Tibetan person, khams skad for the speech of someone from Khams, rong skad for the speech of a farmer (versus 'brog skad — pastoralists' speech), and nyag skad for the speech of someone from the valley of the Nyagchu River, and so on. The scalar polysemy of the Tibetan term 'skad' is anisomorphic with the English terms 'language' and 'dialect', and therefore any attempt to describe Tibet's linguistic diversity in English will inevitably misrepresent Tibetan views of that diversity.

Finally, a focus on delineating and counting languages conceals other forms of linguistic diversity. Anderson, for example, has argued that diversity between genetic groupings above the language level is overlooked by approaches that focus on individual languages. ${ }^{29}$ Genetic diversity, in the case of Tibet, is certainly significant, with representatives of three major phyla: Turkic, Mongolic, and Sino-Tibetan. In addition to overlooking genetic diversity, our approach also draws attention away from dialect diversity and endangerment. ${ }^{30}$ Finally, we may note that linguistic diversity can be assessed at yet another level, that of individual linguistic features, an approach adopted in the World Atlas of Linguistic Structures. ${ }^{31}$ A focus on language overlooks and to some extent obscures diversity at the level of genetic groups, dialects, and features.

Despite the complexities involved with differentiating languages, the valid criticisms raised against the practice, and the manner in which it veils other forms of linguistic diversity, we consider differentiating and enumerating Tibet's minority languages to be of value to both the communities that speak the languages and to the international scholarly community.

27 Gayatri Spivak, 'Can the subaltern speak?' in Marxism and the interpretation of cultures, Cary Nelson and Lawrence Grossber (eds), Macmillan Education, Basingstoke, 1988, pp. 271-313.

${ }^{28}$ Zhou Minglang, 'Minority language policy in China: Equality in theory and inequality in practice' in Language policy in the People's Republic of China: Theory and practice since 1949, Zhou Minglang and Sun Hongkai (eds), Kluwer Academic Publishers, Boston, 2004, pp. 71—96. Possession of an orthography (regardless of whether it is a traditional one or a newly created one) for a specific speech community is often a criterion for regarding a variety as an independent language, as a view taken for the Saami languages, see Pekka Sammallahti, The Saami languages: An introduction, Davvi Girji O.S., Kárášjohka, 1998.

29 Anderson, Gregory, 'Language hotspots'.

${ }^{30}$ Hiroyuki Suzuki, and Sonam Wangmo, 'Language evolution and vitality of Lhagang [Tagong] Tibetan, a Tibetic language as a minority in Minyag Rabgang', International journal of the sociology of language, vol. 245, 2017 (in press).

${ }^{31}$ Matthew S. Dryer, and Martin Haspelmath (eds) The world atlas of language structures online, Max Planck Institute for Evolutionary Anthropology, Leipzig, 2013, http://wals.info, accessed 12 December 2015. 
Firstly, we may note that language identification is the first step in preventing language loss. Language loss, in turn, has numerous negative consequences. For example, language often plays an important role in identity. This may not necessarily be an ethnic identity, but instead sub-ethnic, regional, local, religious, class, or politybased identities. ${ }^{32}$ For those languages which are associated with a distinct identity, the loss of that language is tantamount to the loss of that identity, a common occurrence in the construction of modern ethnic and national identities, equated, by some, with genocide. ${ }^{33}$ Language loss has other negative impacts. For example, it has been demonstrated to have intergenerational impacts on health and well-being, ${ }^{34}$ including suicide rates. ${ }^{35}$ Additionally, differentiating languages based on intelligibility also ensures that communities can benefit from services where clear and effective communication is essential, including healthcare, education, media, and so on. ${ }^{36}$ Identifying languages can therefore serve as the foundations for the recognition and empowerment of vulnerable subaltern groups, and thus has strong links to the pursuit of social justice for their speakers. ${ }^{37}$

Identifying language also has outcomes that benefit both the international scholarly community and the community of speakers. First of all, language, and the oral traditions contained in it, can be an important source for historical reconstructions in the absence of written texts, and can therefore support the creation of autonomous histories beyond the frames provided by written texts and the hegemonic interests they typically represent. Secondly, the identification and description of linguistic diversity provides linguists and others with data enabling investigation of fundamental linguistic questions, including those related to processes of language contact, change, endangerment, and shift. Investigation of these issues should, in turn, provide communities with an informed basis from which to undertake language planning, including maintenance and revitalization.

In seeking to differentiate and enumerate Tibet's minority languages, we hope this article will contribute to conversations about linguistic diversity in Tibet, and the social and political predicaments which are leading to language endangerment, shift,

32 Beth Meriam, 2011, China's' Tibetan 'frontiers': Sharing the contested ground, Global Oriental, Leiden; Gerald Roche, 'The Tibetanization of Henan's Mongols: Ethnicity and assimilation on the Sino-Tibetan Frontier' Asian Ethnicity, vol. 17, no. 1, 2016, pp. 128-149.

33 Tove Skutnabb-Kangas, Linguistic genocide in education or worldwide diversity and human rights? Routledge, London, 2000.

34 Onowa McIvor, Art Napoleon, and Kerissa Dickie, 'Language and culture as protective factors for at-risk communities', Journal of Aboriginal health, vol. 5, no. 1, 2009, pp. 6-25; Margrete J. Bals, Anne Lene Turi, Ingunn Skre, and Siv Kvernmo, 'The relationship between internalizing and externalizing symptoms and cultural resilience factors in Indigenous Sami youth from Arctic Norway', International journal of circumpolar health, vol. 70 no.1, 2011, 37-45.

35 Darcy Hallett, Michael J. Chandler, and Christopher E. Lalonde. 'Aboriginal language knowledge and youth suicide' Cognitive development vol. 22, no.3, 2007, pp. 392-399.

36 People cannot be treated by a doctor they cannot communicate with, cannot learn from a teacher they do not understand, cannot obtain information from media services that are unintelligible to them, and cannot express their political grievances to people who do not understand them. Identifying languages is a critical step in language development, for example, developing orthographies.

${ }^{37}$ Ingrid Piller, Linguistic diversity and social justice: An introduction to applied sociolinguistics, Oxford University Press, Oxford, 2016. 
and loss in the region. Our aim in participating in this conversation is not necessarily a more accurate description of Tibet (though this is certainly welcome) but rather greater recognition and social justice for linguistic minorities in Tibet who are presently vulnerable and marginalized. Therefore, in recognition of our commitment to, but caution about, linguistic differentiation, we do not provide a single enumeration of Tibet's minority languages. Instead, we provide a range of estimates, and reflect critically on the sources they are based on, in order to further discussion about aspects of Tibet's linguistic diversity that may presently be elided in mainstream representations. In moving towards these estimates, the following section discusses the ways in which we have defined Tibet, in order to provide a clear framework for our estimates of the number of minority languages in the region.

\section{Defining Tibet}

We divide the Tibetan regions of China into two parts. The first consists of all administrative units with 'Tibetan autonomous' status (the Tibetan Administrative Area, TAA), while the second includes areas where Tibetans live, but which do not have Tibetan autonomous status (the Nonautonomous Tibetan Area, NTA). Our definition is therefore based on the criteria of administrative status within the People's Republic of China. This is because, as we argue below, probably the greatest factor influencing the vitality of Tibet's minority languages is their differing administrative status - whether the language is recognized by the Chinese state, and where, administratively, its speakers can receive state support. We may therefore think of the TAA as those areas where the Tibetan language has a relatively privileged status, whereas the NTA consists of those areas inhabited by Tibetans, but where the Tibetan language has no special status.

The TAA includes all areas that are designated as Tibetan autonomous districts (regions, prefectures, and counties) within the People's Republic of China (see Appendix 2 and Figure 2, below); it covers an area of 2,201,638 square kilometres, has a total population of $8,585,246$, and therefore a population density of approximately 3.90 people per square kilometre. Reliable demographic data on the distribution of Tibetans in China is difficult to find. However, we assume that the majority of the country's 6.2 million Tibetans reside in the TAA, and probably constitute 65-70 per cent of the area's population, though this proportion would vary considerably throughout the region. And, although there is no single administrative body for the TAA, its constituent administrative units nonetheless form a bloc, in theory at least, insofar as the Tibetan language and Tibetan culture are given special status within this region, though what this precisely means is decided by the governments of the different administrative units.

Beyond the TAA, Tibetans also live natively i.e., not as recent migrants, within the area we call the NTA-see Appendix 3 and Figure 2. The NTA covers an area of 90,915 square kilometres and has a population of $6,539,812$ people, giving a population density of approximately 71.93 people per square kilometre, much higher than that of the TAA. No available data allows us to identify the number of Tibetans in this region, but we estimate that they make up less than less than five per cent of 
the total population of the NTA. Within this area, Tibetan language and culture have no special administrative status.

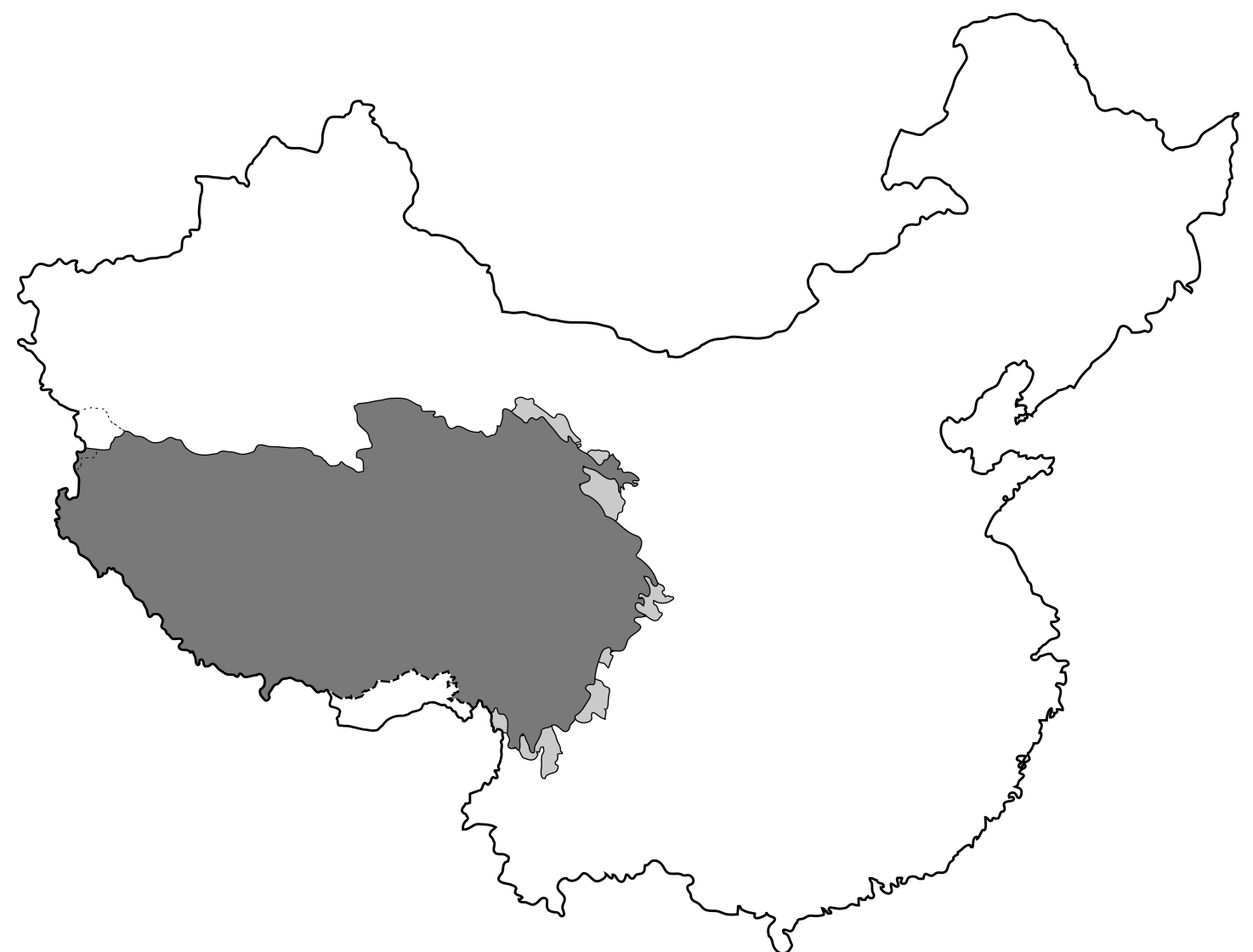

Figure 2. Tibet. The darker shaded areas are the Tibetan Autonomous Areas (TAA) - all the administrative units which are officially recognized as Tibetan autonomous regions, prefectures, or counties. The light grey areas are the Nonautonomous Tibetan Areas (NTA) - counties that do not have official autonomous status, but which contain significant native populations of Tibetans.

\section{Defining Tibet's minority languages}

We define Tibet's minority languages as the non-Tibetic, non-Sinitic languages of Tibet; that is, all languages that are spoken in Tibet - both the TAA and NTA - that are not 'Tibetan' or 'Chinese'. ${ }^{38}$ This genetic criterion is intended to highlight

${ }^{38}$ We have placed Tibetan and Chinese in inverted commas here, since neither of them are languages, but rather clusters of related languages that are often considered to be single languages. From this point onwards in this article, we use the term 'Tibetic' to refer to the languages typically described as 'Tibetan' (Tournadre 2014), and 'Sinitic' for language typically described as 'Chinese'. Regarding the term 'Tibetic languages', Zeisler (2004) employs 'Tibetan languages' instead, however, we prefer the term 'Tibetic' to avoid conflation with the ethnic term 'Tibetan', as Tibetic languages are spoken not only by Tibetans, but also by other ethnic groups - see Tournadre (2014). Additionally, there are also Tibetans who do not speak Tibetic languages, such as rGyalrongic languages, which are often insisted to be 'Tibetan dialects' even by Tibetan scholars such as Wang and bTsan-lha Ngagdbang Tshul-khrims (1992) and Sum-bha Don-grub Tshe-ring (2011:50-51). Tournadre. 'The Tibetic languages and their classification', Bettina Zeisler. Relative tense and aspectual values in Tibetan 
communities that are within, but distinct from, a broader Tibetan context, but do not represent the nationally dominant Han majority. And although the criterion we have used in defining this group is genetic, our aim is sociolinguistic - to identify a group of languages whose social and political predicament places them at risk of endangerment and extinction. This category is analytically useful in that it highlights a group of languages that are politically and socially vulnerable, as they are neither associated with the dominant national language (Putonghua) nor the dominant regional languages (the various Tibetic languages and their prestigious standard, the literary Tibetan language). Due to their political and social status, Tibet's minority languages are more likely to be lower in prestige hierarchies and to be associated with stigmatised social identities; less likely to be present in formal institutions; and their speakers more likely to experience discrimination, marginalization, exclusion, and assimilatory pressures. And although these languages are also 'minority' languages in the sense of being spoken by small numbers of people, the defining features of their minority status are, as outlined above, social and political.

Although our genetic criterion appears relatively simple, there are several borderline cases that need to be considered. Broadly, there are two reasons for such ambiguous cases. One is the fact that much research remains to be done on the genetic affiliation of the region's languages. A second factor, which compounds the first, is the intense contact between languages in the area, and the obscuration of languages' genetic affiliation that this causes. Several examples will demonstrate the issues involved.

The Ngandehua language ${ }^{39}$ is spoken by approximately 4,000 people in eastern Qinghai Province, within the TAA. Janhunen et al. have defined Ngandehua as a Sinitic language, ${ }^{40}$ while Dede maintains that it can equally be characterized as a 'mixed' language with Tibetic and Sinitic roots. ${ }^{41}$ Speakers of Ngandehua are officially classified as Tu (Monguor), but for the most part strongly identify as Tibetans. ${ }^{42}$ They live only in three villages, in a single valley where approximately 75 per cent of residents speak a Tibetic language. Ngandehua's mutual unintelligibility with other local languages, as well as both the self-identity of its speakers and the local demographic reality, make this a language that is firmly within, but distinct from, the Tibetan context. Another language in a similar situation is Daohua, which is

languages: A comparative study, Mouton de Gruyter, Berlin, 2004; Wang Jianmin 王建民 and bTsanlha Ngag-dbang Tshul-khrims. Anduoyu Jiaronghua duibi fenxi 安多语嘉戎话对比分析, Sichuan Minzu Chubanshe, Chengdu, 1992; Sum-bha Don-grub Tshe-ring. Bod skad kyi yul skad rnam shad. Krung go'i bod rig pa dpe skrun khang, Beijing, 2011.

${ }^{39}$ This is the name used by the community to refer to the language. Linguists call it Wutun/ Wutunhua - see Juha Janhunen, Marja Peltomaa, Erika Sandman, and Xiawu Dongzhou, Wutun, Lincom Europa, München, 2008.

40 Janhunen et al, Wutun.

${ }^{41}$ Keith Dede, 'Mixed languages', in Encyclopaedia of Chinese language and linguistics, Rint Sybesma (ed), Brill, Leiden, 2015 (forthcoming). A position contesting the existence of 'mixed languages' can be found in George van Driem, Languages of the Himalayas: An ethnolinguistic handbook of the greater Himalayan region, Brill, Leiden, 2001.

${ }^{42}$ Tshe ring skyid, 'An introduction to Rgya tshang ma, a Monguor ( $\mathrm{Tu}$ ) village in Reb gong (Tongren)', Asian highlands perspectives, vol. 37, 2015, pp. 276-300. 
spoken by almost 3,000 Tibetans in Yajiang County, Sichuan Province. ${ }^{43} \mathrm{We}$ include both Daohua and Ngandehua in our estimates of the number of Tibet's minority languages. Even though their genetic affiliations do not make their inclusion in this category clear-cut, their sociolinguistic predicaments do.

Baima, spoken by approximately 10,000 Tibetans in northern Sichuan and Southern Gansu, is another example of a language with controversial genetic affiliation. Although often classified as belonging to the (non-Tibetic) Qiangic group of languages, both Chirkova ${ }^{44}$ and Tournadre ${ }^{45}$ argue that it is a Tibetic language. Complicating this controversy is the issue of identity. ${ }^{46}$ Speakers of Baima are officially classified as Tibetans. However, they have, in the past, contested this definition, and requested to be classified as a separate ethnic group. ${ }^{47}$ This means that even if their language is Tibetic, their identity places a social barrier between themselves and surrounding Tibetans, suggesting that, socially, if not also in terms of intelligibility, Baima speakers constitute a discrete community, thus once again satisfying the criteria of being within a Tibetan context, but distinct from it. We therefore include Baima in our discussion of minority languages in Tibet.

This brings us to a final group of languages which, in contrast to the languages dealt with above, we will not discuss in this article, namely, that of Tibetic varieties which can be considered minority languages either at a local scale, or more broadly throughout the Tibetan region. An example of a locally minoritized Tibetic language is that spoken by the inhabitants of Shaowa Township in Chone County in southern Gansu Province. ${ }^{48}$ This Tibetic variety was considered so aberrant from the local vernacular that villagers came to consider themselves as being ethnically distinct from other Tibetans, and they therefore applied, successfully, to be reclassified as Tu (Monguor). Another example is the indigenous Tibetic variety spoken around Lhagang Monastery in western Sichuan. ${ }^{49}$ With increasing urbanization and immigration in the township around the monastery, this local Tibetic variety has now become endangered. At the broader regional level, we may note that many Tibetic varieties are also socially and politically marginalized, in that they do not conform to

\footnotetext{
${ }^{43}$ The term Daohua, however, may also be used by local Tibetans to designate a similar ('mixed') variety spoken in surrounding counties such as Daofu. Kun dga' dBang mo 根呷翁姆 and Hiroyuki Suzuki 鈴木博之, 'Daofuyu de shiyong qingkuang he yuyan huoli: Xianshuizhen Daofuyu de gean yanjiu 道孚语的使用情况和语言活力: 鲜水镇道孚语的个案研究', Kyoto University linguistic research, vol. 27, 2008, pp. 223-240.

${ }^{44}$ Katia Chirkova, 'On the position of Baima within Tibetan: A look from basic vocabulary', in Evidence and counter-evidence: Festschrift for F. Kortland, Volume 2: General linguistics, Alexander Lubotsky, Jos Schaeken, and Jeroen Wiedenhof (eds), Rodopi, Amsterdam, 2008, pp. 69—91.

45 Tournadre, 'The Tibetic languages'.

46 Tricia Kehoe, 'I am Tibetan? An exploration of online identity construction among Tibetans in China', Asian ethnicity, vol. 16, no. 3, 2015, pp. 314-333.

47 Janet L. Upton, 'Notes towards a native Tibetan ethnology: An introduction to and annotated translation of dMu dge bSam gtan's essays on Dwags po (Baima Zangzu)', Tibet journal, vol. 25, no. 1, 2000, pp. 3-26.

${ }^{48}$ Juha Janhunen, Lionel Ha Mingzong, and Joseph Tshe dpag rnam rgyal, 'On the language of the Shaowa Tuzu in the context of the ethnic taxonomy of Amdo Qinghai', Central asiatic journal, vol. 51, no.2, 2007, pp. 177-195.

${ }^{49}$ Hiroyuki Suzuki and Sonam Wangmo, 'Language evolution and vitality'.
} 
folk perceptions of Tibetan dialectology which classify all Tibetic forms into three dialects: Amdo, Khams, and Ü-Tsang. Most of the Tibetic languages spoken in Chone, Thewo, and Drugchu counties in southern Gansu, for example, fall into this category. ${ }^{50}$ However, although these locally and regionally marginalized Tibetic languages share important sociolinguistic characteristics with Tibet's minority languages, they are distinct in two important senses. First is that they share a clear, and more or less clearly perceived, relationship with the literary Tibetan language that forms the nucleus of Tibetan linguistic identity. Second is that the speakers of all these languages are unambiguously classified and perceived as Tibetans. These two characteristics place these marginalized Tibetic varieties in a sociolinguistic category that requires separate treatment from Tibet's minority languages, and we therefore do not include them in our estimates of the number of Tibet's minority languages.

\section{Categorizing Tibet's minority languages}

In order to differentiate between the sociolinguistic predicament of these minority languages, and the differing levels of vulnerability these predicaments entail, we present a sociolinguistic categorization of Tibet's various minority languages. Using Roche's ${ }^{51}$ tentative categorization, we divide Tibet's minority languages into three groups, based on two criteria: political and geographic. The first criterion refers to whether or not the language is associated with an officially recognized minzu (nationality/ ethnic group), under the assumption that languages which are associated with an officially recognized minzu are less vulnerable to endangerment and shift than those that are not. ${ }^{52}$ The second criterion refers to whether or not an officially recognized group has a formally recognized territory within Tibet associated with its population. This is significant because, in China, all linguistic rights are provided through the territorial administrative system, rather than on a communal or individual basis. In addition to looking at the existence of a territorial basis for ethnic recognition, we also examine the distribution of the group's designated ethnic territory in terms of whether it falls exclusively within Tibet or not. Based on the

\footnotetext{
${ }^{50}$ Tournadre, 'The Tibetic languages and their classification'. All of these varieties are classified as 'Choni' in the Ethnologue. One of the important contributions of Tournadre for the languages of southern Gansu is the observation that typologically similar languages are also spoken in its surroundings such as Jiuzhaigou, Songpan and Baxi District of Ruoergai. They are certainly a minority within the Tibetic languages and have never been officially treated as independent groups, as Choni in Ethnologue. Tournadre puts all of them under the section called 'Eastern' with Ethnologue's Choni. However, Suzuki provides a different classification based on an analysis combining the historical linguistic methodology with the mutual intelligibility. Regarding the languages of Jiuzhaigou, Songpan, and Baxi District of Ruoergai, see Hiroyuki Suzuki 鈴木博之, 'Gannan-syuu Zhuoni-DiebuZhouqu 3-ken no Tibetto-kei syogengo to sono kaibunrui siron 甘南州卓尼・迭部・舟曲 3 県のチ ベット系諸言語とその下位分類試論’, Nidaba, vol. 44, 2015, pp. 1-9.

51 Roche, 'The Tibetanization of Henan's Mongols'.

${ }^{52}$ In the various legal mechanisms that deal with language in China, no minority languages are formally recognized by name; in fact, only Putonghua, Modern Standard Chinese, is mentioned by name. However, in practice, each minzu is considered to have a single standard language that is protected by law.
} 
intersection of these two criteria of recognition and territory, we identify three groups among Tibet's minority languages, each of which we describe more fully below: extraterritorial languages, enclaved languages, and unrecognized local languages.

Both the extraterritorial and enclaved languages are officially recognized by the Chinese state as being associated with one of China's 56 minzu. In theory, at least, each of these groups has a constitutionally guaranteed right to use and develop their language. However, extraterritorial and enclave languages differ in that the enclave languages have a territorial base that falls exclusively inside Tibet, whereas the territorial base of extraterritorial languages is primarily outside of the region. This demographic base might be within China, outside of Tibet, or, in the case with several languages spoken in the Tibet Autonomous Region (TAR), it may fall outside the country altogether. We call these domestic and international extraterritorial languages, respectively. For the domestic extraterritorial languages, although they have the right to use and develop their languages within China, this applies only within their territorially defined homelands, and not within Tibet. This means that, within the Tibetan context, these languages are vulnerable to local extinctions, though this may not greatly impact the overall vitality of the language as a whole. The situation of international extraterritorial languages is primarily defined by the existence of the national border between India and China, which limits contact between the two populations, essentially depriving the international extraterritorial languages of any chance to benefit from whatever rights the languages are provided with in India.

Two examples will illustrate the diversity within the extraterritorial languages. The Nuosu language is spoken by approximately two million people of the officially recognized Yi ethnicity, and is also designated as the prestige standard for the approximately 7.7 million people who are classified as belonging to this group. ${ }^{53}$ This language has a demographic and institutional base in the Liangshan Yi Autonomous Prefecture in southern Sichuan Province, and is also spoken in communities within the TAA ${ }^{54}$ and NTA. $^{55}$ A somewhat different example of an extraterritorial language is provided by the Dakpa (Cuona Menba) language. It is spoken by about 1,300 people in China, all of whom are officially classified as belonging to the Monpa ethnicity, a group with no formal territorial base in China. The majority of the language's speakers, a further 8,600 people, live in the Tawang region, an area controlled by India but claimed by China, where they constitute a locally dominant demographic majority.

Compared with the extraterritorial languages, the enclaved languages of Tibet typically find themselves in a relatively well-supported political and social situation. Although they are surrounded by a dominant Tibetan society, they can, (in theory) obtain legal protection from assimilatory pressures within their territory. The Salar

\footnotetext{
${ }^{53}$ David Bradley, 'Language policy for the Yi', in Perspectives on the Yi of southwest China, Stevan Harrell (ed), University of California Press, Berkeley, 2001, pp.195-214.

${ }^{54}$ For example, in Muli Tibetan Autonomous County in Liangshan Yi Autonomous Prefecture, Jiulong County in Ganzi Tibetan Autonomous Prefecture, and Shangri-La Municipality in Diqing Tibetan Autonomous Prefecture.

${ }^{55}$ For example in Ninglang Yi Autonomous County in Lijiang Municipality.
} 
language can be considered a paradigmatic case of an enclaved language. Salar, a Turkic language, is spoken by approximately 70,000 people, mostly in Xunhua Salar Autonomous County in Qinghai Province. The territorialization of the Salar language, in theory, provides a mechanism whereby the language can receive government support, for example, in the realm of education, though in practice this is not done. This potential for language support, however, can be usefully contrasted with the fate of the many Salar-speakers who migrate, permanently or temporarily, to urban centres in Qinghai and elsewhere in China, who are immersed in non-Salar speaking communities and cannot receive any support for their language in terms of education, media, or interactions with the government.

Among the enclaved languages are several that we call 'peripheral enclaved languages'. As the name suggests, these languages are enclaved at the edges of the Tibetan world. The sociolinguistic predicament of these languages is distinct from that of the other enclaved languages, which are subject to the policy and legal contexts of the Chinese state and to social dynamics and a cultural milieu that are primarily Tibetan. In contrast, the peripheral enclaved languages must often negotiate social contexts that are more complex, involving the dynamics of both the majority Han society and minority Tibetan society, or which involve other, locally dominant minority groups, such as the Yi. The Yugur languages of western Gansu are one example of peripheral enclaved languages. The Yugur live to the north of the Tibetan Plateau in the foothills of the Qilian Mountains, within the predominantly Han Hexi Corridor. Culturally, they share many features with Tibetans, including the practice of Tibetan Buddhism, but socially and politically, they are within a Han majority context. The Qiang people are another example. Speaking several closely related, poorly documented languages, the Qiang people live in an area that borders the Han Chinese lowlands of the Sichuan basin to the east, and the Tibetan Rgyalrong region to the west; in the past, many Qiang areas were administered by the Rgyalrong chieftains, and some Qiang-speakers are presently identified as Tibetans. ${ }^{56}$ Again, what we have here is an example of languages that are adjoined to, but not necessarily subsumed within, a Tibetan context.

The final category of Tibet's minority languages is the unrecognized languages. Unrecognized languages exist when a single minzu speaks more than one language. In China's present policy framework, only one language is typically recognized as the language which a minzu may use and develop. All other languages are unrecognized. For example, among the Naxi, at least four languages are spoken: Laze, Malimasa, Narua, and Naxi. In this case, Naxi is the paradigmatic 'roofing' language that serves as the standard ethnic language, ${ }^{57}$ whereas Laze, Malimasa, and Narua are unrecognized languages. In the Tibetan case, the unrecognized minority languages are the non-Tibetic languages spoken by people in Tibet who are officially classified as Tibetans. These languages and their speakers lack any formal recognition that would distinguish them from mainstream Tibetans who speak the various Tibetic languages.

\footnotetext{
${ }^{56}$ For the controversy surrounding this classification, see Wen Maotao, The creation of the Qiang ethnicity, its relation to the Rme people and the preservation of Rme language, MA thesis, Duke University, 2014.

57 Kloss, 'Abstand and Ausbau languages'.
} 
And since they do not officially speak a distinct language, they of course also lack any territorial basis upon which to provision the freedom to use and develop their languages. Many of the speakers of these languages accept their designation as Tibetans, and consider their languages to be 'dialects' of Tibetan. This is the case for most speakers of such languages as Mawo Rma (Qiang), Northern Prinmi (Pumi), Lizu, Doxu, Namuyi, Rta'u, and Shuhing (Shixing/ Xumi). There are also, however, people who are classified as Tibetan but who do not identify themselves as such, and do not consider their language to be Tibetan. These include speakers of Baima, Ersu, and Darang Deng.

The relationship between ascribed and professed identity, ethnic autonomy, and language support can be complex, as the case of the officially recognized Tu people demonstrates. The Tu, living mostly in eastern Qinghai Province, speak at least four mutually unintelligible languages: Mangghuer, Mongghul, Manegacha, and Ngandehua; some Monguor have also shifted to the local variety of Qinghai Chinese (North-western Mandarin). The government recognizes only a single Tu language which the Tu have the constitutional freedom to use and develop. Paradigmatically, this is the Mongghul language, spoken only by Tu living in Huzhu Tu Autonomous County. ${ }^{58}$ The other Tu languages-Manegacha, Mangghuer, and Monggghul — can be considered unrecognized languages, even though Mangghuer is spoken in a county that is officially designated as a Tu autonomous county. Manegacha and Ngandehua present a still more complicated situation. They are spoken within the TAA by people who, for the most, part, contest the state's ascribed identity and profess Tibetan identity.

We expect the categories outlined above to correlate with different levels of language endangerment. First of all, we expect the unrecognized languages to be the most endangered of Tibet's minority languages. Since state support for a language is based on official recognition within the framework of ethnic classification, from which these languages have been erased, they are exposed to a de facto statesponsored assimilation program. We expect enclaved and extraterritorial languages, by contrast, to have relatively higher vitality, since they have the benefit of receiving state recognition and support. However, for extraterritorial languages, this support is generally not offered within Tibet. So, although each extraterritorial language, as a whole, should be expected to have relatively high vitality, within Tibet, these languages are unsupported (although recognized) and should be expected to have relatively lower vitality, roughly equivalent to that of the unrecognized languages, since they have no territorial basis upon which to receive state support.

As a final note on the sociolinguistic classification of Tibet's minority languages, we may note that the categories described above operate differently inside the TAA and the NTA. Since we have based our classification primarily on policies linked to the territorial implementation of ethnic autonomy, the categories we suggest are obviously more influential inside the TAA. Within that context, the logic of ethnic classification and its linguistic implications produce the institutions responsible for

\footnotetext{
${ }^{58}$ Limusishiden and Keith Dede, 'The Mongghul experience: Consequences of language policy shortcomings', International journal of the sociology of language, vol. 215, 2012, pp. 101-124.
} 
defining and reproducing languages, and thus have significant structuring consequences within the TAA. Within the NTA, however, the logic of ethnic classification lacks the administrative power it has in the TAA, as it is divorced from the territorial basis through which that logic is expressed. Within the NTA, we may therefore speak of the classificatory resonance of these categories, rather than their administrative power. Within the NTA, the logic of ethnic classification has the power to shape individual identities, subjectivities, life trajectories, and so on, but not to create institutions that produce and reproduce language.

In the following section, we provide several estimates of the number of minority languages in Tibet, according to different sources. For each estimate, we distinguish between languages spoken in the TAA and NTA. We also indicate, for each language, if it is an extraterritorial, enclaved, or unrecognized language according to the criteria above. In constructing the estimates below, we have excluded several types of languages which nonetheless classify as minority languages of Tibet: sign languages; writing systems; and argots, jargons, and secret languages. The diverse writings systems of the region require separate consideration from the languages considered here, whereas the other languages excluded from our survey are presently in need of much more research before they could be included. Full details of the languages included in the counts can be found in the appendices.

\section{Counting Tibet's minority languages}

Our first estimate provides a list of officially recognized minzu in the TAA and NTA (Appendix 5). In cases where a population occurs in both, we have placed them where they primarily live, and noted their presence elsewhere. In state policy discourse and practice, each of these minzu has a single language, based on a written standard, which they have the right to use and develop; although the relevant legal frameworks, including the constitution, are vague on the precise number of languages that each minzu may use, de facto practice assigns a single language to each minzu. ${ }^{59}$ We have excluded Han (Chinese) and Zang (Tibetans) from this count, and have also excluded the many migrant populations of other minzu. This count gives a total of 14 languages, with four in the TAA and ten in the NTA. Within the TAA, 25 per cent $(n=1)$ are extraterritorial and 75 per cent $(n=3)$ are enclaved, while in the NTA, 70 per cent $(n=7)$ are extraterritorial and 30 per cent $(n=3)$ are enclaved. There are no unrecognized languages according to this estimate. In terms of the number of people who speak these languages, available statistics make it difficult to determine the total number of speakers within Tibet, but if we look at the total national populations of these languages, however, we find the following. The minority languages within the TAA have an average of $1,576,415$ speakers, but this average is skewed heavily by the large number of Mongolian speakers (5,981,840); the median-160,069-gives a clearer picture of the size of a typical minority language in the TAA. Within the NTA, the average speaker population is $1,219,890$, but again this is skewed by languages with large populations: Yi $(8,714,393)$ and Bai $(1,933,510)$; the median

\footnotetext{
${ }^{59}$ Zhou, 'Minority language policy in China'.
} 
speaker population in the NTA is 210,086 . We therefore suggest that, according to the view from state ethnic classification, languages in the NTA are more likely to be larger than those in the TAA (see Figure 3).

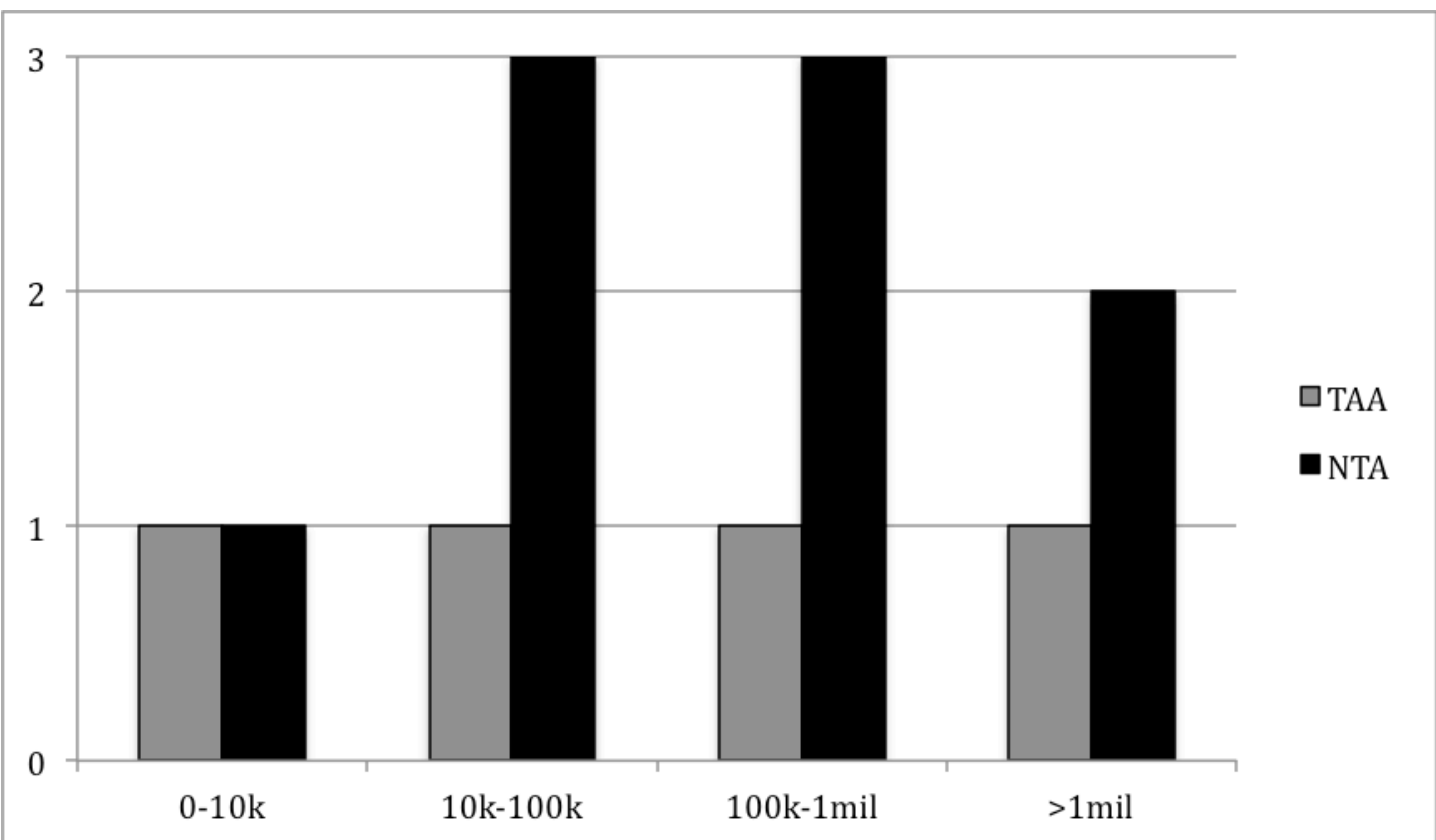

Figure 3. Number of languages (1-3) in the TAA and NTA by number of speakers according to our minzu-based estimate. The NTA has more languages, with larger speaker populations, than the TAA.

Although in practice each minzu is considered to speak a single language, linguists in China have long recognized that many nationalities in fact speak more than one language. For example, Sun Hongkai, who has worked extensively on China's Tibeto-Burman languages, has stated that, 'of the 55 national minorities in China, 15 (27.7 per cent) use more than two languages'. ${ }^{60}$ Our second estimate is therefore based on two recent reference works on Chinese linguistics research: Report on the Language Situation in Life in China (Zhongguo Yuyan Shenghuo Zhuangkuang Baogao) ${ }^{61}$ and Languages of China (Zhongguo de Yuyan) (Appendix 6). ${ }^{62}$ Again, dividing languages into the TAA or NTA was not always unambiguous, and so we have made note of more complex cases in the relevant appendix. This count gives a total of 33 languages, with 21 being spoken in the TAA and 12 in the NTA; the most significant difference between this and the previous count is the increase in the number of languages spoken in the TAA. Within the TAA, 9.5 per cent $(n=2)$ are extraterritorial, 14.3 per cent $(n=3)$ are enclaved, and 76.2 per cent $(n=16)$ are

\footnotetext{
${ }^{60}$ Sun Hongkai, 'On nationality and the recognition of Tibeto-Burman languages' Linguistics of the Tibeto-Burman area, vol.15, no. 2, 1992, p. 2.

61 Zhou Qingsheng 周庆生 (ed), Zhongguo Yuyan Shenghuo Zhuangkuang Baogao 2005 中国语言 生活状况报告 2005, Shangwu Yinshuguan, Beijing, 2006.

${ }^{62}$ Sun Hongkai 孙宏开, Hu Zengyi 胡增益 and Huang Xing 黄行. Zhongguo de yuyan 中国的语言 , Shangwu Yinshuguan, Beijing, 2007.
} 
unrecognized. Within the NTA, 41.7 per cent $(n=5)$ are extraterritorial, 33.3 per cent $(n=4)$ are enclaved, and 25 per cent $(n=3)$ are unrecognized.

The two most obvious differences between this and the previous estimate are: the increase in the number of languages in the TAA relative to the NTA (a trend which continues in subsequent estimates), and the rise in number of unrecognized languages. Demographic data presented in Zhongguo Yuyan Shenghuo Zhuangkuang Baogao also allows us to discuss population sizes. Within the TAA, the average population size of minority languages is 152,070, while in the NTA it is 506,047. However, if we remove the extraterritorial languages, which have significant populations outside the target regions, we find that the gap in size narrows, with 23,867 speakers per language in the TAA and 31,081 in the NTA. As with the previous estimates, languages of the NTA are, on average, larger, though the typical number of speakers is lower than in the previous estimate (see Figure 4), and the gap between average populations sizes in the TAA and NTA has narrowed in this estimate. Finally, according to the figures contained in these sources, approximately 3.97 per cent of the 6.2 million Tibetans in China speak an unrecognized language.

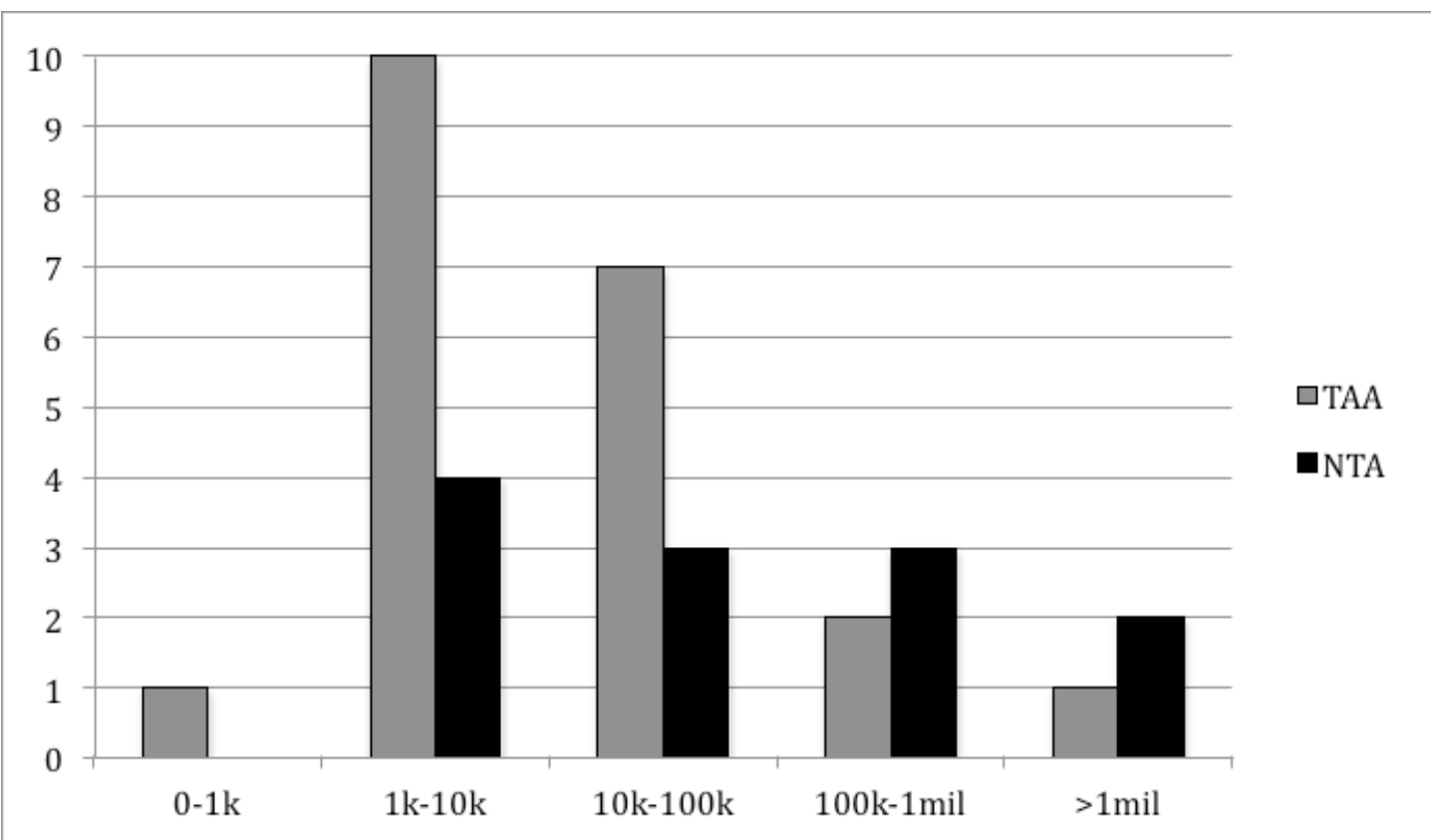

Figure 4. Number of languages in the TAA and NTA by number of speakers, according to the Chinese reference literature. Small languages predominate in the TAA.

The next estimate comes from the Ethnologue, which describes itself as a 'comprehensive reference work cataloguing all of the world's known living languages ${ }^{63}$ and is created and maintained by SIL International, 'a faith-based nonprofit organization committed to serving language communities worldwide. ${ }^{64}$ The curators of Ethnologue are responsible for dispensing ISO 639-3 codes, the only

\footnotetext{
${ }^{63} \mathrm{http}: / /$ www.ethnologue.com/, accessed 12 December 2015.

64 http://www.sil.org/about, accessed 12 December 2015.
} 
internationally recognized formal identification for languages. Given the controversy surrounding SIL International's simultaneous roles as a scientific and religious organization with both descriptive (language identification) and prescriptive (language support) functions, ${ }^{65}$ an alternative reference catalogue, Glottolog, which also issues its own stable persistent identifiers for languages (Glottocodes) has also been established. ${ }^{66}$ Nonetheless, the Ethnologue is not only 'the most widely consulted inventory of the world's languages used today' (increasingly through the Ethnologue Data Set ${ }^{67}$ but also 'at present better than any other non-derivative work of the same scope ${ }^{96}$ and we therefore consult it here.

An examination of the $18^{\text {th }}$ edition of the Ethnologue (released in 2015) gives a total of 43 languages, with 25 in the TAA and 18 in the NTA (Appendix 7). Once again, the main difference between this and the prior count is in the increased number of languages identified as being spoken in the TAA. Within the TAA, 32 per cent $(n=8)$ are extraterritorial, 12 per cent $(n=3)$ are enclaved, and just over half (56 per cent, $\mathrm{n}=14$ ) are unrecognized, whereas within the NTA the proportion of extraterritorial languages drops to 22.2 per cent $(n=4)$, while the proportion of enclaved languages rises to 22.2 per cent $(n=4)$ and the percentage of unrecognized languages remains slightly higher than half, with 55.6 per cent $(n=10)$.

The data presented in Ethnologue also enable two additional analyses, in terms of population numbers and language vitality. Regarding the size of languages in terms of speaker numbers, languages of the NTA have a much wider range, from 950 to two million speakers (compared to $80-130,000$ in the TAA). Minority languages in the NTA, on average, have more speakers than within the TAA, with 198,453 and 20,049 speakers on average, respectively. Even if we remove the extraterritorial languages, which often have large populations outside the target area, the average number of speakers for minority languages in the NTA is still larger-47,011, compared to 19,702 for the TAA; this follows the pattern seen in the previous two estimates. According to the Ethnologue, therefore, the TAA is home to more, smaller languages, which are also more likely to be unrecognized or extraterritorial, while the NTA is home to fewer but larger languages that are less likely to be unrecognized and more likely to be enclaved (see Figure 5). Finally, we can also note that, according to population statistics in the Ethnologue, approximately 3.77 per cent of China's 6.2 million Tibetans speak an unrecognized language, and estimate very close to the previous 3.97 per cent.

\footnotetext{
${ }^{65}$ Lise Dobrin (ed). 'Special collection: SIL International and the disciplinary culture of linguistics', Language vol. 85 no. 3, 2009, pp. 618-658.

${ }^{66} \mathrm{http} / / / \mathrm{glottolog}$. org/, accessed 12 December 2015.

${ }^{67}$ https://www.ethnologue.com/product/ethnologue-global-dataset, accessed 12 December 2015.

${ }^{68}$ Harald Hammarström, 'Ethnologue 16th/17th/18th editions: comprehensive review', Language, vol. 91, no.3, 2015, pp. 723.
} 


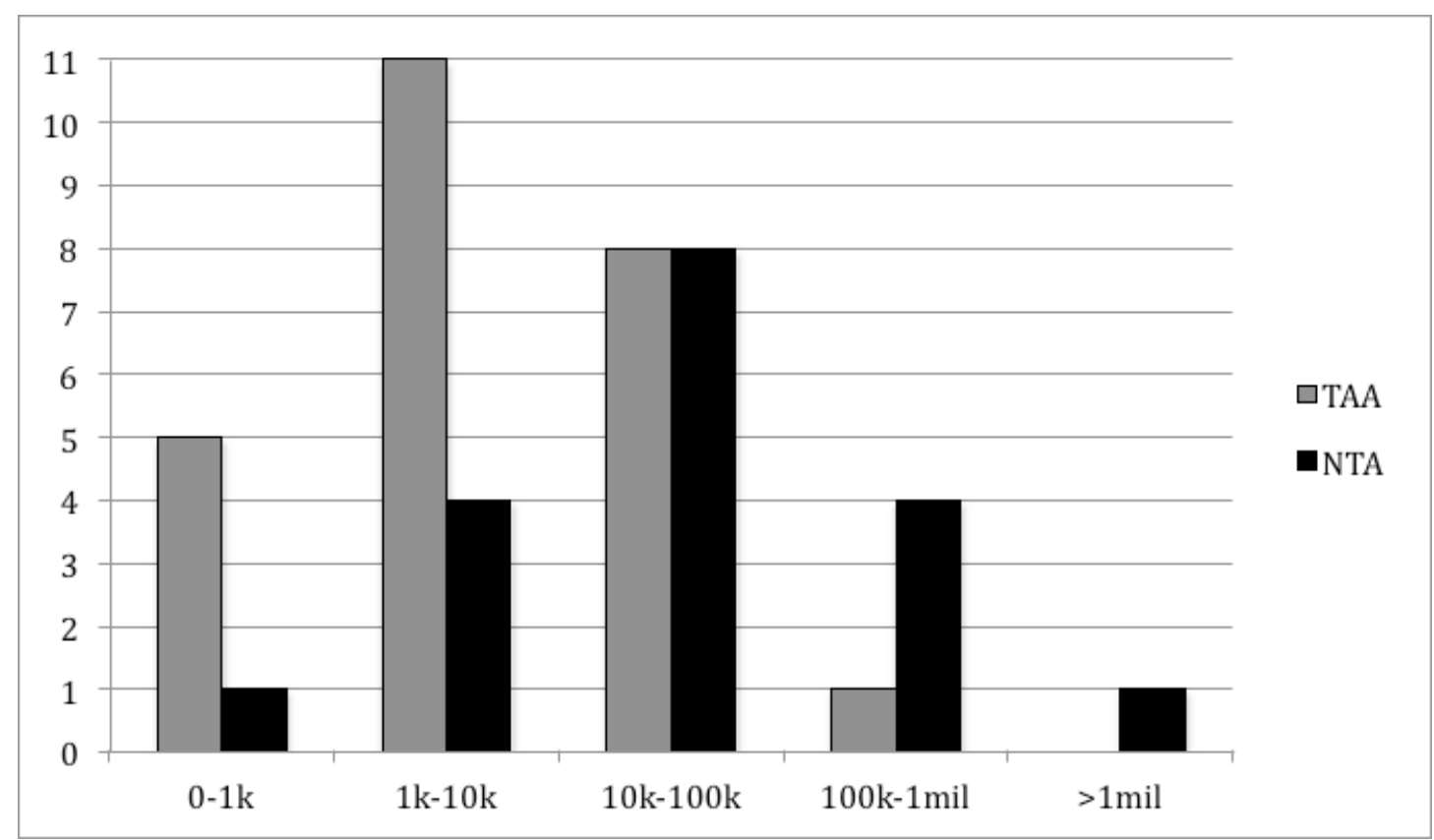

Figure 5. Number of languages in the TAA and NTA by number of speakers according to our Ethnologue-based estimate. Both the TAA and NTA have a large number of languages with less than 10,000 speakers. The NTA differs from the TAA in having more languages with over 100,000 speakers.

The Ethnologue data also enables us to analyse Tibet's minority languages in terms of endangerment, as every language listed is also ranked on a 'language status' scale, known as EGIDS (Expanded Graded Intergenerational Disruption Scale), that ranges from International (0), through 'Developing (5), Shifting (7), to Extinct (10). All languages which are ranked as 'Threatened' (6b) or higher can be considered endangered. Using this information, we see that 68 per cent of minority languages in the TAA $(n=17)$ are endangered to some extent. Among these, 5.9 per cent $(n=1)$ are 'Moribund'; 41.2 per cent $(n=7)$ are 'Shifting'; and 52.9 per cent $(n=9)$ are 'Threatened', meaning that although over half of the TAA's minority languages are endangered, amongst these, a majority are endangered to the lowest degree possible. Meanwhile, 32 per cent $(n=8)$ of all of the TAA's minority languages are vigorous; none rank higher on the EGIDS. Within the NTA, although the majority of languages are endangered to varying degrees (61 per cent, $n=11)$, we also find three languages with vitality levels above 'Vigorous': Naxi is described as 'Developing (5)', Nuosu as 'Educational' (4), and Lisu as a 'Language of Wider Communication' (3). Among the endangered languages of the NTA, 18.2 per cent $(n=2)$ are 'Moribund'; 18.2 per cent (2) are 'Shifting', and 63.6 per cent $(n=7)$ are 'Threatened'. Four (22.2 per cent) of the NTA's minority languages are described as 'Vigorous', meaning that, as with the minority languages within the TAA, although over half of the NTA's minority languages are endangered, the level of endangerment for most is relatively low. On average, languages within the TAA are more endangered than those in the NTA; using the numbers assigned to each category in the EGIDS, we find that languages in the TAA average a score of 6.54-just over the threshold of 'Threatened' (6.5) - 
whereas those in the NTA average 6.19-closer to 'Vigorous' (6). We can also look at vitality from the perspective of our sociolinguistic categories: extraterritorial, enclaved, and unrecognized. If we average the numerical value of the EGIDS categories for each of our sociolinguistic categories, we find the following: extraterritorial languages average 6.23; enclaved languages 6.25; and unrecognized languages 6.45. This suggests that, on average, Tibet's minority languages are all somewhere between vigorous (6) and threatened (6.5), regardless of their sociolinguistic category, though the unrecognized languages are, on average, more likely to be threatened.

A third estimate can be gleaned from a wider variety of literature beyond the Ethnologue, since, as the editors acknowledge 'Ethnologue ... always lags behind the reality in spite of our best efforts with a limited staff to keep up. ${ }^{69}$ We began this estimate by consulting Ethnologue's 'Change Request Index', which lists all languages currently under investigation for inclusion in Ethnologue ${ }^{70}$ but did not find any relevant entries there. We therefore turned to the wider linguistic literature for our third estimate. We consulted 65 separate sources in English, Chinese, and Japanese, covering a temporal range from the 1980s until today, though the vast majority of them were published since 2000 (see the Appendix 8 for relevant sources). They include journal articles, $\mathrm{PhD}$ and MA dissertations, and published monographs. An important note regarding these sources is that most of them describe 'doculects' - 'a linguistic variety as it is documented in a given resource' that is 'deliberately agnostic as to whether or not that variety can straightforwardly be associated with a particular "language"". ${ }^{71}$ Very few of the sources deliberately attempt to delineate language boundaries, or provide detailed areal contextualization that allows an unambiguous understanding of the relationship between the doculect and other languages in the region.

In surveying the contemporary literature, we now find 60 languages spoken in Tibet as a whole, with 43 in the TAA and 17 in the NTA. Once again, the most significant increase here is in the number of languages in spoken in the TAA, where extraterritorial languages make up 23.2 per cent $(n=10)$, enclaved languages make up 4.7 per cent $(n=2)$, and unrecognized languages makes up 72.1 per cent $(n=31)$. Within the NTA, extraterritorial languages make up 29.4 per cent $(n=5)$, enclaved languages 17.7 per cent $(n=3)$, and unrecognized languages 52.9 per cent $(n=9)$. Due to the inconsistency of the information made available by the sources consulted for this estimate, we are unable to analyse patterns in speaker population and language vitality. However, if we deploy the correlation between vitality and sociolinguistic category suggested by our the analysis of the Ethnologue data, we can see that both within the NTA and TAA, the relatively vital enclaved languages constitute a minority, while the less vital unrecognized languages are the largest group in both areas.

69 http://www.ethnologue.com/ethnoblog/m-paul-lewis/how-not-use-ethnologue\#.VgixHU3smUk, accessed 12 December 2015.

${ }^{70} \mathrm{http}$ //www-01.sil.org/iso639-3/chg_requests.asp, accessed 12 December 2015.

${ }^{71}$ Michael Cysouw and Jeff Good, 'Languoid, Doculect, and Glossonym: Formalizing the Notion "Language", Language documentation and conservation, vol. 7, 2012, p. 342. 
To complete our range of estimates, we look at on-going and unpublished research in order to assess to what extent the above estimate, based on recently published work, is likely to expand in the near future.

Several 'new' languages are currently under investigation in the TAA. Suzuki and Sonam Wangmo ${ }^{72}$ briefly mention Lhagang Choyu, and describe it as a heavily endangered, unrecognized language spoken in a single hamlet in Kangding Municipality. It is now very rarely spoken in daily life, by fewer than 100 people, and has for the most part been replaced by Khams Tibetan. Its basic vocabulary is most similar to Choyu; low intelligibility with Choyu is assumed. This language awaits a detailed description.

According to research currently being conducted by Hiroyuki Suzuki, South-central rGyalrong, discussed by Gates, ${ }^{73}$ could potentially be divided into two languagesbTsanlha and Chuchen. These languages, though phonologically divergent, ${ }^{74}$ still retain a relatively high level of mutual intelligibility. However, three factors warrant considering them as separate languages. First is that the two populations are physically isolated from each other, being separated by speakers of Geshitsa and Khams Tibetan. Secondly, the two populations were ruled by different chieftains in the past, and were thus attached to different local identities. Finally, bTsanlha is spoken by people officially classified as both Tibetans and Qiang, whereas Chuchen is only spoken by Tibetans.

On-going research by Sims ${ }^{75}$ suggests, following Evans and Sun, ${ }^{76}$ that Qiang should be treated as a cluster of related languages rather than a single language. He also suggests that the current division into a Northern Qiang and Southern Qiang languages is inadequate. He examines what he calls the Merr language, which he claims does not fit the North-South division. He also suggests that the Qiang languages be renamed the Rmaic languages, following the local autonym. A great deal of research remains to be done in reviewing the classification of these languages, however, reference grammars are already available for several varieties, such as Mawo, ${ }^{77}$ Yadu, ${ }^{78}$ Qugu, ${ }^{79}$ and Puxi. ${ }^{80}$

72 Hiroyuki Suzuki and Sonam Wangmo, 'Discovering endangered Tibetic varieties in the easternmost Tibetosphere: a case study on Dartsendo Tibetan', Linguistics of the Tibeto-Burman area, vol. 38, no.2, 2015, pp. 256-270; Hiroyuki Suzuki, and Sonam Wangmo, 'Lhagang Choyu: A first look at its sociolinguistic status', Studies in Asian geolinguistics, vol. 2, 2016 (in press).

73 Jesse P. Gates, Situ in situ: Towards a dialectology of Jiāróng (rGyalrong), Lincom Europa, München, 2014. Jesse P. Gates, Intelligibility, identity, and structure in Western rGyalrongic. Paper presented at 3rd workshop of Sino-Tibetan Languages of Sichuan. Paris, 2-4 September, 2013.

74 See data presented at the rGyalrongic Languages Database: http://htq.minpaku.ac.jp/databases/rGyalrong/.

${ }^{75}$ Nathaniel Sims, 'A phonology and lexicon of the Yonghe Variety of Qiang', Linguistics of the Tibeto-Burman area, vol. 37, no.1, 2014, pp. 34-74. Nathaniel Sims, 'Towards a more comprehensive understanding of Qiang dialectology', Language and linguistics, vol. 17, no.3, 2016, pp. 351-381. Nathaniel Sims, forthcoming, 'Testing intelligibility within the "Qiang" language(s)'.

76 Jonathan Evans and Jackson Sun, 'Qiang', in Encyclopedia of Chinese language and linguistics Rint Sybesma (ed), Brill, Leiden, 2013 (forthcoming).

${ }^{77}$ Liu Guangkun 刘光坤, Mawo Qiangyu yanjiu 麻窝㒸语研究, Sichuan Minzu Chubanshe, Chengdu, 1998. 
Another significant area of contemporary research concerns Tibetan Sign Language. Theresia Hofer, at Oxford University, is presently conducting research on this topic. Her research has suggested that an unknown number of 'village' and 'home' signing systems were previously used throughout Tibet, and that now, a provisional standardized form is emerging in Lhasa, which has been recognized as the first minority sign language in China. ${ }^{81}$ Much more research needs to be done to determine if any of the village or home varieties formed stable, intergenerational systems that might be called distinct sign languages.

Within the NTA, the only language in possible need of revision that we are aware of is the Trung (Drung) language. From the perspective of Trung speakers, this language actually consists of two independent languages: Trung and Nung. Linguists have referred to the latter as 'Anu' 82 or 'Anong', 83 regarding it as the Nujiang dialect of Trung. According to Hiroyuki Suzuki's research, the term Anu is not used as an autonym. Nung is used instead, as the Chinese character ' $n u$ ' is always pronounced 'nung' locally. 84

A final note is necessary before concluding this section. Although we consulted several Tibetan works in compiling the third estimate above, they were a conspicuous minority. In fact, it seems that there is very little Tibetan literature on the region's minority languages, ${ }^{85}$ and none at all that seeks to identify and enumerate the minority languages of Tibet. We suggest that this is due, in part, to the persistent emphasis placed on prescriptive grammatical studies focusing on the written language, in recognition of grammatology's place among the 'five major sciences' of the traditional Tibetan canon. Furthermore, it is important to note the conspicuous underdevelopment of modern, descriptive linguistics in the Tibetan context. Although Tibetan language articles on descriptive linguistics appear in various journals, and passing mention is made of some minority languages in Tibetan language ethnographies, there are no Tibetan language journals specifically dedicated to linguistics. Nor are there any formal programs for training linguists in Tibetan, or

78 Randy J. LaPolla and Huang Chenglong, A grammar of Qiang: With annotated texts and glossary, Mouton De Gruyter, Berlin, 2003.

${ }^{79}$ Huang Bufan 黄布凡 and Zhou Facheng 周发成, Qiangyu yanjiu 㒸语研究, Sichuan Renmin Chubanshe, Chengdu, 2006.

${ }^{80}$ Huang Chenglong 黄成 $\square$, Puxi qiangyu yanjiu 蒲溪㒸语研究, Minzu Chubanshe, Beijing, 2007.

81 Theresia Hofer, 'Is Lhasa Tibetan Sign Language emerging, endangered, or both?', International journal of the sociology of language, vol. 245, 2017; Tibet Deaf Association. Bod kyi rgyun spyod lag brda'i tshigs mdzod, Bod ljongs mi rigs dpe skrun khang, Lhasa, 2011.

${ }^{82}$ Sun Hongkai 孙宏开, Huang Chenglong 黄成 $\square$, and 'Brug mo mtsho 周毛草, Rouruoyu yanjiu 柔若语研究, Zhongyang Minzu Daxue Chubanshe, Beijing, 2002.

${ }^{83}$ Sun Hongkai and Liu Guangkun, A grammar of Anong: Language death under intense contact. Translated, annotated, and supplemented by Li Fengxiang, Ela Thurgood, and Graham Thurgood, Brill, Leiden, 2009.

${ }^{84}$ Qin Liying and Hiroyuki Suzuki, 'Chasing a cat from the Mekong to the Salween: A geolinguistic description of "cat" in Trung and Khams Tibetan in North-western Yunnan', Studies in Asian geolinguistics, vol. 1, 2015, pp. 61-71.

${ }^{85}$ See, for example, Sum bha don grub tshe ring. Bod skad kyi yul skad rnam shad. 
standard reference works on linguistics in Tibetan that cover the minority languages being discussed here.

Based on the above research, it seems that the number of identified languages in Tibet may expand in coming years, bringing the total into the mid-sixties. But, it is unlikely that any significant number of new languages will be discovered, and most efforts are likely to be concentrated on clarifying linguistic sub-classification of already-known languages. However, there are still geographically less-investigated areas, where it is possible that more languages may be discovered. For example, the border areas between Muli and Jiulong-Yajiang are not well-investigated, and locals there claim the existence of unstudied languages. The peripheral region of the Tibet Autonomous Region is another area where future research may be productive. Much work still also remains to be done beyond identifying new languages, in terms of describing the languages that have been identified and in exploring their internal variation and geographical distribution, to say nothing of the enormous amount of sociolinguistic research that urgently needs to be carried out in order to better understand issues related to language vitality, endangerment, and shift in Tibet.

\section{Discussion}

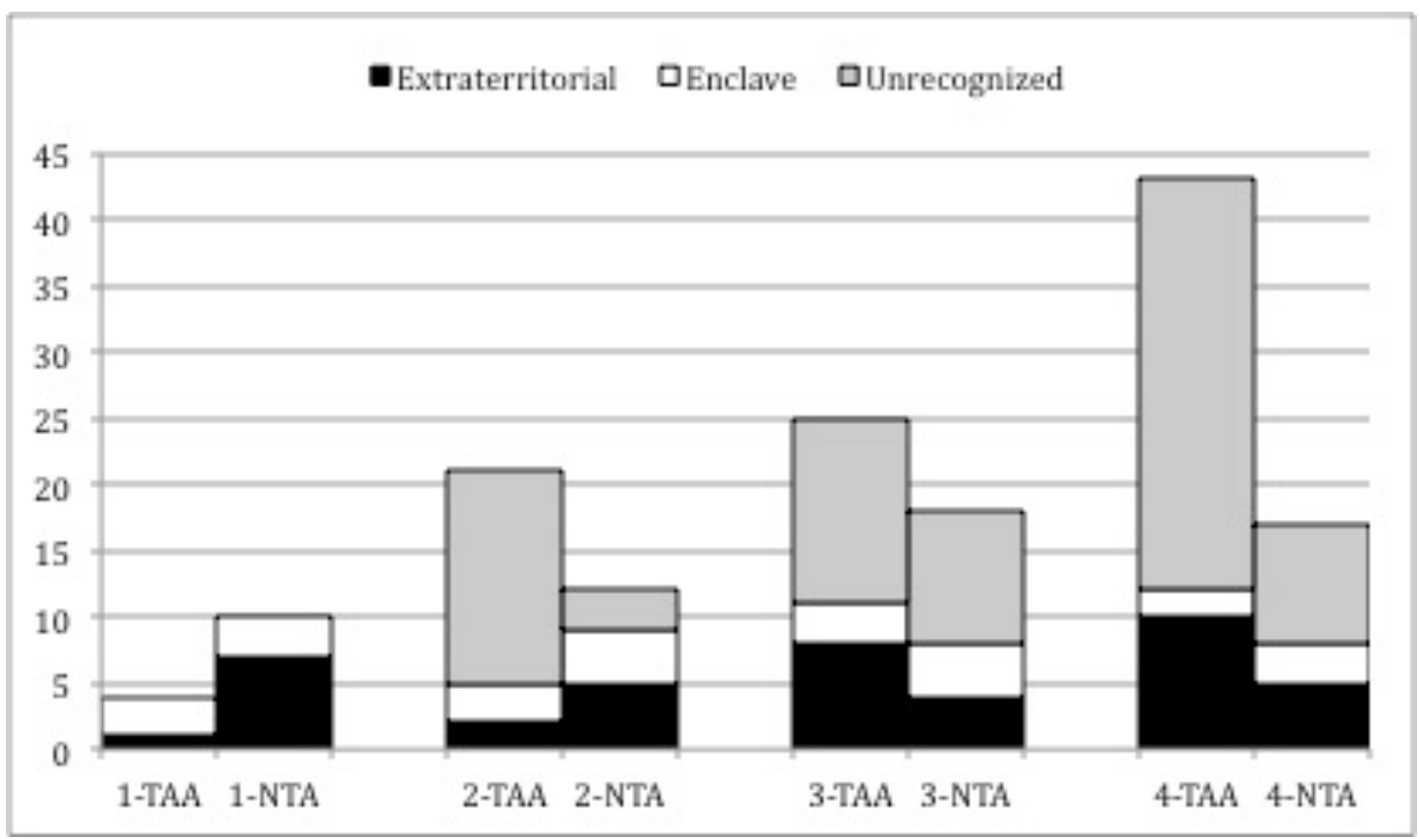

Figure 6. Comparison of the estimates given above, broken into sociolinguistic categories. The numbers $1,2,3$, and 4 refer, respectively, to estimates based on the state classification system, Chinese language reference works, Ethnologue, and contemporary linguistic literature.

We begin our discussion of the data by looking at patterns that remain stable across the estimates (see Figure 6). The most stable pattern is that the number of enclaved languages remains relatively unchanged across the four estimates, with $2-3$ in the TAA and 3-4 in the NTA - also indicating that in most estimates, the number of enclaved languages in the TAA and NTA are approximately equal. Another relatively 
stable pattern is that, in all except the first estimate, the number of languages in the TAA is greater than in the NTA, which seems reasonable given the region's larger size and population. We also find that, in all estimates, the languages of the NTA have more speakers than those in the TAA (see Figures 3-5). Finally, we may also note that in the two estimates that contain consistent demographic information, we see that between 3.5 and four per cent of Tibetan in China speak a minority language.

The differences between the estimates are more numerous and more interesting than the similarities. We can begin by noting that the number of extraterritorial languages varies more between estimates than the number of enclaved languages: from 1-9 in the TAA and 4-7 in the NTA. Furthermore, in the estimates based on ethnic classification and Chinese reference literature, the NTA has more extraterritorial languages, whereas in the Ethnologue and new literature estimates, the TAA has more extraterritorial languages, and this is due primarily to the increased number of languages identified as being spoken in the TAR, mostly near the border with India. Far more variable than the extraterritorial languages, however, are the unrecognized languages. Estimates for the number of unrecognized languages vary from $0-16$ in the TAA and $0-10$ in the NTA, and their proportional contribution also varies widely, between 52 and 76.2 per cent in the TAA (excluding the ethnic classification estimate) and between 25 and 55.6 per cent in the NTA (again, excluding the ethnic classification estimate). Overall, comparing the TAA and the NTA, we see that the estimates vary more for the TAA than the NTA.

There are two possible ways to interpret the differences between the four estimates. The first is that we can assume that the four estimates represent a linear series, arranged according to the degree of centralization and conservatism of the institutions responsible for delineating the languages. In this view, the Chinese government, with its ethnic classification program, is the most conservative and centralized institution, and accordingly provides the lowest estimate for the number of minority languages spoken in Tibet. The number of languages identified then steadily rises in each estimate, as centralization and conservatism decrease, with the least centralized and least conservative institution, the international linguistic community, providing the highest estimate.

An alternative way to interpret the variation in our data is to assume that the four estimates are independent, rather than a linear series, and that each estimate represents the unique profile and goals of the various institutions. Viewed in this way, we may note the following. The first estimate is distinguished from the others by its absence of unrecognized languages, in recognizing relatively few languages, and also in recognizing more languages in the NTA than in the TAA. These observations are all consistent with a centralized government that wishes to promote national unity through linguistic homogenization whilst simultaneously maintaining a semblance of support for ethnic minorities and attempting to promote linguistic unity through ethnic classification within the Tibetan administrative areas. Then, if we compare this with the estimate derived from the Chinese reference literature, in the context of the two remaining estimates, we may interpret the Chinese reference literature as a compromise between the state's political goals and the academy's scientific goals. What is significant in this count is the appearance of unrecognized languages and the 
readjustment of the balance between the TAA and NTA, with the TAA showing more languages, as in all subsequent estimates, and which, as we state above, is almost certainly correct given the size and population of the TAA. In looking at the Ethnologue estimate, we might describe it as being the result of an international faithbased scientific organization attempting to find equilibrium between its oftencompeting goals of community descriptive linguistics and prescriptive language development. One obvious difference between this and the previous count is that SIL's international profile enables it to compare languages spoken in India and Nepal with those spoken in the TAR, leading to an increase in the number of extraterritorial languages identified. Finally, when we look at the final estimate, we may note that the description of doculects is, to some extent, financially incentivized under present funding regimes, where support for language documentation is comparatively easier to obtain than funding for linguistic surveys, intelligibility testing, and other methods of linguistic differentiation; this has particularly been the case since around the year 2000, a time during which the majority of our sources were published.

A view that balances both the above interpretations is most likely reasonable: the differing estimates most likely arise as a result of decreasing centralization and conservatism across the institutions, as well as from the differing and unrelated agendas of the relevant institutions. Given this, can we say that any one estimate is correct, or more correct than the others? Unfortunately not. None of the estimates is entirely objective - each is based on a unique organizational politic and institutional agenda. Nonetheless, in concluding this article, we wish to discuss why we still consider it important to continue research that will help bring clarity to this issue.

\section{Conclusion}

Based on our sociolinguistic classification, all but one of the four estimates discussed here suggest that language endangerment is a widespread, but not necessarily intense, predicament for Tibet's minority languages, with approximately two thirds of Tibet's minority languages experiencing some degree of endangerment. This suggests that, regardless of how many minority languages are spoken in Tibet, it is likely that there will be fewer in 100 years' time if current conditions prevail. We therefore consider it imperative that work continues on identifying and describing the region's minority languages, with the aim of both supporting the sustainability of individual languages, and providing data of adequate quality and quantity to support future revitalization efforts where necessary.

In this context, attempting to accurately identify the number of minority languages is important. Underestimating the diversity will contribute to the dialectization of distinct languages, and exacerbate the process of endangerment and ensuing loss of languages. Meanwhile, we should also consider the possibility of overestimating the number of languages. As seen above, the number of identified languages has increased with the growing attention being paid to the region by linguists, a trend which is likely to continue. Any overestimation of the number of languages may lead to the creation of ausbau languages, resulting not only in scarce resources being divided amongst an unnecessarily high number of communities, but also in enforcing 
linguistic boundaries that have no salience for local populations. An accurate enumeration of Tibet's minority languages must therefore avoid two extremes: erasure of existing diversity through underestimation, and reification of non-existent diversity through overestimation.

Ultimately, what constitutes an accurate estimate must be judged by the people who identify with these languages. The delineation and enumeration of Tibet's minority languages should be based on the perceptions and priorities of the relevant populations, including the use of language names that are preferred by the community (see Appendix 9) ${ }^{86}$ We still know very little about the linguistic attitudes and ideologies of the speakers of Tibet's minority languages, and this remains a significant topic for further research. However, any study of such topics must take into account the political and social constraints under which these attitudes are formed, the extent to which they might be subject to 'misrecognition'-the obfuscating effects of power. ${ }^{87}$ Furthermore, even if we are able to take speakers' attitudes into account in the future, it will still be necessary to have a better understanding of the linguistic diversity of the region in terms of intelligibility, lexical similarity, and spatial distribution, so that the linguistic community can play a role in language planning - helping local communities define, create, and support the languages that they wish to maintain into the future.

If this is done well, respectfully, and quickly, it may be possible for Tibet to avoid a fate which seems to await most of Asia, the world's most linguistically diverse continent - a drastic decline in linguistic diversity, as the countries of the region delve headlong into some of the most rapid economic development and modernization in human history, and, perhaps, towards a linguistic future very much like present-day Australia, the USA, or Europe, where the revitalization of moribund and dormant languages is a more prevalent concern than the maintenance of healthy ones.

\footnotetext{
${ }^{86}$ On this issue, see Tunzhi (Sonam Lhundrop), 'Language vitality and glottonyms in the ethnic corridor: The Rta'u language', International journal of the sociology of language, vol. 245, 2017 (in press).

${ }^{87}$ Pierre Bourdeiu, Language and Symbolic Power, Malden, Polity Press, 1991.
} 


\section{Appendices}

Appendix 1: Number of Languages per province according to the Ethnologue.

\begin{tabular}{|c|c|}
\hline Provincial-Level Admin Unit & No. of Languages \\
\hline Anhui & 3 \\
\hline Beijing & 2 \\
\hline Chongqing & 2 \\
\hline Fujian & 8 \\
\hline Gansu & 12 \\
\hline Guangdong & 9 \\
\hline Guangxi & 41 \\
\hline Guizhou & 46 \\
\hline Hainan & 8 \\
\hline Hebei & 3 \\
\hline Heilongjiang & 8 \\
\hline Henan & 1 \\
\hline Hubei & 4 \\
\hline Hunan & 18 \\
\hline Jiangsu & 1 \\
\hline Jiangxi & 6 \\
\hline Jilin & 3 \\
\hline Liaoning & 3 \\
\hline Inner Mongolia & 8 \\
\hline Ningxia & 1 \\
\hline Qinghai & 9 \\
\hline Shaanxi & 1 \\
\hline
\end{tabular}




\begin{tabular}{|lr|}
\hline Shanghai & 1 \\
\hline Shanxi & 1 \\
\hline Sichuan & 31 \\
\hline Xinjiang & 17 \\
\hline Xizang & 20 \\
\hline Yunnan & 155 \\
\hline Zhejiang & 5 \\
\hline
\end{tabular}

Appendix 2: Tibetan Administrative Areas. Each category also includes all subordinate administrative units. For example, the Tibet Autonomous Regions includes all prefectures in the region; Yushu Tibetan Autonomous Prefecture includes all counties in the prefecture, and so on.

\begin{tabular}{|c|c|c|}
\hline Province-Level & Prefecture-Level & County-Level \\
\hline \multicolumn{3}{|c|}{ Tibetan Autonomous Region $^{88}$} \\
\hline \multirow[t]{6}{*}{ Qinghai Province } & \multicolumn{2}{|c|}{ Yushu Tibetan Autonomous Prefecture } \\
\hline & \multicolumn{2}{|c|}{ Guoluo Tibetan Autonomous Prefecture } \\
\hline & \multicolumn{2}{|c|}{ Hainan Tibetan Autonomous Prefecture } \\
\hline & \multicolumn{2}{|c|}{ Haibei Tibetan Autonomous Prefecture } \\
\hline & \multicolumn{2}{|c|}{ Haixi Tibetan and Mongolian Autonomous Prefecture } \\
\hline & \multicolumn{2}{|c|}{ Huangnan Tibetan Autonomous Prefecture } \\
\hline \multirow[t]{2}{*}{ Gansu Province } & \multicolumn{2}{|c|}{ Gannan Tibetan Autonomous Prefecture } \\
\hline & Wuwei Municipality & $\begin{array}{l}\text { Tianzhu Tibetan Autonomous } \\
\text { County }\end{array}$ \\
\hline \multirow[t]{3}{*}{ Sichuan Province } & \multicolumn{2}{|c|}{ Aba Tibetan and Qiang Autonomous Prefecture } \\
\hline & \multicolumn{2}{|c|}{ Ganzi Tibetan Autonomous Prefecture } \\
\hline & $\begin{array}{l}\text { Liangshan Yi } \\
\text { Autonomous Prefecture }\end{array}$ & $\begin{array}{l}\text { Muli Tibetan Autonomous } \\
\text { County }\end{array}$ \\
\hline Yunnan Province & \multicolumn{2}{|c|}{ Diqing Tibetan Autonomous Prefecture } \\
\hline
\end{tabular}

Appendix 3: Administrative Units of the Nonautonomous Tibetan Areas.

\begin{tabular}{|lll|}
\hline Province-Level & Prefecture-Level & County-Level $^{89}$ \\
\hline Qinghai Province & Xining Municipality & \\
\hline
\end{tabular}

\footnotetext{
${ }^{88}$ However, we do not include the area claimed by China but controlled by India, which they refer to as Zangnan and Arunachal Pradesh respectively.

${ }^{89}$ Although officially identified Tibetan towns and townships do exist (see Appendix 4), these have no role in terms of autonomy.
} 


\begin{tabular}{|c|c|c|}
\hline & Haidong Municipality & \\
\hline \multirow[t]{2}{*}{ Gansu } & Zhangye Municipality & $\begin{array}{l}\text { Sunan Yugur Autonomous } \\
\text { County }\end{array}$ \\
\hline & Longnan Municipality & Wen \\
\hline \multirow[t]{7}{*}{ Sichuan Province } & Mianyang Municipality & Pingwu \\
\hline & Liangshan Yi Autonomous & Mianning \\
\hline & & Ganluo \\
\hline & & Yuexi \\
\hline & Ya'an Municipality & Hanyuan \\
\hline & & Shimian \\
\hline & & Baoxing \\
\hline \multirow[t]{4}{*}{ Yunnan Province } & Lijiang Municipality & $\begin{array}{l}\text { Yulong Naxi Autonomous } \\
\text { County }\end{array}$ \\
\hline & & Yongsheng \\
\hline & & $\begin{array}{l}\text { Ninglang Yi Autonomous } \\
\text { County }\end{array}$ \\
\hline & $\begin{array}{l}\text { Nujiang Lisu Autonomous } \\
\text { Prefecture }\end{array}$ & $\begin{array}{l}\text { Gongshan Dulong and } \mathrm{Nu} \\
\text { Autonomous County }\end{array}$ \\
\hline
\end{tabular}

Appendix 4: Tibetan Towns and Townships

\begin{tabular}{|llll|}
\hline $\begin{array}{l}\text { Province- } \\
\text { Level }\end{array}$ & $\begin{array}{l}\text { Prefecture- } \\
\text { Level }\end{array}$ & County & Township \\
\hline Gansu & $\begin{array}{l}\text { Zhangye } \\
\text { Municipality }\end{array}$ & $\begin{array}{l}\text { Sunan Yugur } \\
\text { Atuonomous } \\
\text { County }\end{array}$ & Qifeng Zangzu Xiang \\
\cline { 2 - 4 } & $\begin{array}{l}\text { Longnan } \\
\text { Municipality }\end{array}$ & Dangchang County & Xinchengzi Zangzu Xiang \\
\cline { 3 - 4 } & Wudu District & Pingya Zangzu Xiang \\
\cline { 3 - 4 } & Maidong & Moba Zangzu Xiang \\
\cline { 3 - 4 } & Municipality & $\begin{array}{l}\text { Mutonomous } \\
\text { County }\end{array}$ & Tielou Zangzu Xiang \\
\cline { 3 - 4 } & & Xunhua Salar & Wendu Zangzu Xiang \\
\hline
\end{tabular}




\begin{tabular}{|c|c|c|c|}
\hline & \multirow{3}{*}{$\begin{array}{l}\text { Autonomous } \\
\text { County }\end{array}$} & Galeng Zangzu Xiang \\
\hline & & & Daowei Zangzu Xiang \\
\hline & & & Gangcha Zangzu Xiang \\
\hline & & \multirow{4}{*}{$\begin{array}{l}\text { Hualong Hui } \\
\text { Autonomous } \\
\text { County }\end{array}$} & Chapu Zangzu Xiang \\
\hline & & & Xiongxian Zangzu Xiang \\
\hline & & & Jinyuan Zangzu Xiang \\
\hline & & & Tajia Zangzu Xiang \\
\hline & & \multirow[t]{2}{*}{ Ledu District } & Zhongba Zangzu Xiang \\
\hline & & & Xiaying Zangzu Xiang \\
\hline & & \multirow{2}{*}{$\begin{array}{l}\text { Huzhu Tu } \\
\text { Autonomous } \\
\text { County }\end{array}$} & Songduo Zangzu Xiang \\
\hline & & & Bazha Zangzu Xiang \\
\hline & \multirow{5}{*}{$\begin{array}{l}\text { Xining } \\
\text { Municipality }\end{array}$} & Huangyaun County & Riyue Zangzu Xiang \\
\hline & & \multirow[t]{2}{*}{ Huangzhong County } & Qunjia Zangzu Xiang \\
\hline & & & Machang Zangzu Xiang \\
\hline & & \multirow{2}{*}{$\begin{array}{l}\text { Datong Hui and } \mathrm{Tu} \\
\text { Autonomous } \\
\text { County }\end{array}$} & Xianghua Zangzu Xiang \\
\hline & & & Shuobei Zangzu Xiang \\
\hline \multirow[t]{4}{*}{ Sichuan } & \multirow{4}{*}{$\begin{array}{l}\text { Mianyang } \\
\text { Municipality }\end{array}$} & \multirow[t]{4}{*}{ Pingwu County } & Baima Zangzu Xiang \\
\hline & & & Muzuo Zangzu Xiang \\
\hline & & & Mupi Zangzu Xiang \\
\hline & & & Kuoda Zangzu Xiang \\
\hline
\end{tabular}




\begin{tabular}{|c|c|c|}
\hline & & Huya Zangzu Xiang \\
\hline & & Tucheng Zangzu Xiang \\
\hline & & Sier Zangzu Xiang \\
\hline & Beichuan County & $\begin{array}{l}\text { Qingpian Qiangzu Zangzu } \\
\text { Xiang }\end{array}$ \\
\hline Ya'an & Baoxing County & Yaoji Zangzu Xiang \\
\hline & Hanyuan County & Xiaobao Zangzu Yizu Xiang \\
\hline & Shimian County & Caoke Zangzu Xiang \\
\hline & & Wajiao Yizu Zangzu Xiang \\
\hline & & Xinmin Zangzu Yizu Xiang \\
\hline & & Xieluo Zangzu Xiang \\
\hline & & Xianfeng Zangzu Xiang \\
\hline Liangshan Yi & Yuexi County & Baoan Zangzu Xiang \\
\hline Prefecture & Mianning County & Heai Zangzu Xiang \\
\hline
\end{tabular}

Appendix 5: Minority languages of Tibet identified according to state ethnic policies. Population statistics (final column) are based on the 2010 national census and come from Guo Rongxiang, Uradyn E Bulag, Michael A Crang, Thomas Herberer, Eui-Gak Hwang, James Milward, Morris Rossabi, Gerard A Postiglione, Chih-yu Shih, Nicholas Tapp, and Luc Changlei Guo (eds), Multicultural China: A Statistical Yearbook (2014), Springer, New York, 2015.

5.1 TAA

\begin{tabular}{|l|l|l|}
\hline Name & Classification & Population \\
\hline Luoba & Enclave & 3,682 \\
\hline Menba & Enclave & 10,561 \\
\hline Qiang & Enclave (peripheral) & 309,576 \\
\hline Mongol & Extraterritorial & $5,981,840$ \\
\hline
\end{tabular}




\subsection{NTA}

\begin{tabular}{|lll|}
\hline Name & Classification & Population \\
\hline Bai & Extraterritorial & $1,933,510$ \\
\hline Dulong & Extraterritorial & 6,930 \\
\hline Lisu & Extraterritorial & 702,839 \\
\hline Naxi & Extraterritorial & 326,295 \\
\hline Nu & Extraterritorial & 37,523 \\
\hline Pumi & Extraterritorial & 42,861 \\
\hline Sala & Enclave & 130,607 \\
\hline Tu & Enclave (peripheral) & 289,565 \\
\hline Yi & Extraterritorial & $8,714,393$ \\
\hline Yugu & Enclave (peripheral) & 14,378 \\
\hline
\end{tabular}

Appendix 6: Minority languages of Tibet identified according to recent reference works on Chinese linguistic research. Language names are based on Zhou's Zhongguo Yuyan Shenghuo Zhuangkuang Baogao while population estimates (final column) are based on Sun et al's Zhongguo de yuyan.

6.1 TAA

\begin{tabular}{|lll|}
\hline Name & Classification & Population \\
\hline Baoan & Extraterritorial & 10,000 \\
\hline Bogaer & Unrecognized & 3,000 \\
\hline Cangluo & Unrecognized & 5,000 \\
\hline Dao & Unrecognized & 2,685 \\
\hline Darang & Unrecognized & 6,000 \\
\hline Ergong & Unrecognized & 35,000 \\
\hline Geman & Unrecognized & 7,000 \\
\hline
\end{tabular}

${ }^{90}$ Also within the TAA in Huangnan TAP. 


\begin{tabular}{|lll|}
\hline Guiqiong & Unrecognized & 7,000 \\
\hline Jiarong & Unrecognized & 100,000 \\
\hline Kangjia & Unrecognized & 487 \\
\hline Lawu & Unrecognized & 10,000 \\
\hline Menba & Enclave & 40,000 \\
\hline Menggu & Extraterritorial & $2,730,000$ \\
\hline Muya & Unrecognized & 10,000 \\
\hline Pumi & Unrecognized & 58,600 \\
\hline Qiang & Enclave (peripheral) & 130,000 \\
\hline Queyu & Unrecognized & 20,000 \\
\hline Shixing & Unrecognized & 2,000 \\
\hline Wutun & Unrecognized & 2,000 \\
\hline Yidu & Enclave & 7,000 \\
\hline Zhaba & Unrecognized & 7,700 \\
\hline
\end{tabular}

\subsection{NTA}

\begin{tabular}{|lll|}
\hline Name & Classification & Population \\
\hline Bai & Extraterritorial & $1,100,000$ \\
\hline Baima & Unrecognized & 14,000 \\
\hline Dongbu Yugu & Enclave (peripheral) & 3,500 \\
\hline Dulong & Extraterritorial & 5,000 \\
\hline Ersu & Unrecognized & 20,000 \\
\hline Lisu & Extraterritorial & 500,000 \\
\hline Namuyi & Unrecognized & 5,000 \\
\hline Naxi & Extraterritorial & 250,000 \\
\hline Sala & Enclave & 70,000 \\
\hline
\end{tabular}




\begin{tabular}{|lll|}
\hline Tuzu & Enclave (peripheral) & 100,000 \\
\hline Xibu Yugu & Enclave (peripheral) & 5,069 \\
\hline Yi & Extraterritorial & $4,000,000$ \\
\hline
\end{tabular}

Appendix 7: Minority languages of Tibet identified according to the Ethnologue.

7.1 TAA

\begin{tabular}{|c|c|c|c|c|}
\hline Name & $\begin{array}{c}\text { ISO 639- } \\
3\end{array}$ & Pop. & Classification & Vitality \\
\hline Boga'er Luoba & adi & 1,090 & Extraterritorial & Vigorous \\
\hline Bonan & peh & 6,000 & Extraterritorial & Shifting \\
\hline Cuona Monba & twm & 1,300 & Extraterritorial & Threatened \\
\hline Darang Deng & $\mathrm{mhu}$ & 850 & Unrecognized & Threatened \\
\hline Geman Deng & $\mathrm{mxj}$ & 200 & Unrecognized & Threatened \\
\hline Guiqiong & gqi & 6,000 & Unrecognized & Vigorous \\
\hline Horpa & ero & 45,000 & Unrecognized & Vigorous \\
\hline Jiarong & jya & 25,000 & Unrecognized & Vigorous \\
\hline Kalmyk Oirat & xal & 130,000 & Extraterritorial & Shifting \\
\hline Kangjia & kxs & 1,000 & Unrecognized & Moribund \\
\hline Lavrung & jiq & 50,000 & Unrecognized & Vigorous \\
\hline Muya & mvm & 10,000 & Unrecognized & Threatened \\
\hline Northern Pumi & pmi & 35,000 & Enclave & Vigorous \\
\hline Northern Qiang & cng & 57,800 & Unrecognized & Shifting \\
\hline Puroik & suv & 20,000 & Extraterritorial & Vigorous \\
\hline Queyu & qvy & 7,000 & Unrecognized & Threatened \\
\hline Shixing & sxg & 1,800 & Unrecognized & Threatened \\
\hline Southern Qiang & qxs & 81,300 & Enclave & Shifting \\
\hline
\end{tabular}




\begin{tabular}{|lllll|}
\hline \multicolumn{4}{c}{ (peripheral) } \\
\cline { 1 - 4 } sTodsde & jih & 4,100 & Unrecognized & Vigorous \\
\hline Thangmi & thf & 300 & Extraterritorial & Shifting \\
\hline Tshangla & tsj & 7,000 & Extraterritorial & Threatened \\
\hline Wutunhua & wuh & 2,000 & Unrecognized & Shifting \\
\hline Yidu Luoba & clk & 80 & Enclave & Threatened \\
\hline Zhaba & zhb & 7,800 & Unrecognized & Threatened \\
\hline Zakhring & zkr & 600 & Extraterritorial & Shifting \\
\hline
\end{tabular}

7.2 NTA

\begin{tabular}{|lllll|}
\hline Name & $\begin{array}{l}\text { ISO } \\
\text { 639-3 }\end{array}$ & Population & Classification & Vitality \\
\hline Bai, Lama & lay & 60,000 & Unrecognized & Vigorous \\
\hline Baima & bqh & 10,000 & Unrecognized & Threatened \\
\hline Drung & duu & 14,000 & Extraterritorial & Vigorous \\
\hline East Yugur & yuy & 4,000 & $\begin{array}{l}\text { Enclave } \\
\text { (peripheral) }\end{array}$ & Moribund \\
\hline Ersu & ers & 20,000 & Unrecognized & Shifting \\
\hline Lang'e & yne & 2,000 & Unrecognized & Vigorous \\
\hline Lipo & lpo & 250,000 & Unrecognized & Threatened \\
\hline Lisu & lis & 600,000 & Extraterritorial & $\begin{array}{l}\text { Wider } \\
\text { Communicati } \\
\text { on }\end{array}$ \\
\hline Namuyi & nmy & 5,000 & Unrecognized & Threatened \\
\hline Narua & nru & 47,000 & Unrecognized & Threatened \\
\hline Naxi & nxq & 300,000 & Extraterritorial & Developing \\
\hline Southern Pumi & pmj & 19,000 & Unrecognized & Vigorous \\
\hline
\end{tabular}




\begin{tabular}{|lllll|}
\hline Nuosu & iii & $2,000,000$ & Extraterritorial & Educational \\
\hline Salar & slr & 70,000 & Enclave & Threatened \\
\hline Talu & yta & 13,600 & Unrecognized & Threatened \\
\hline Tanglang & ytl & 950 & Unrecognized & Threatened \\
\hline Tu & mjg & 152,000 & $\begin{array}{l}\text { Enclave } \\
\text { (peripheral) }\end{array}$ & Shifting \\
\hline West Yugur & ybe & 4,600 & $\begin{array}{l}\text { Enclave } \\
\text { (peripheral) }\end{array}$ & Moribund \\
\hline
\end{tabular}

Appendix 8: Minority languages of Tibet identified according to recent literature. In this count, we have marked one or two key sources for each language, but in consideration of the space available, we have excluded references to the vast literature that exists on these many languages.

\subsection{TAA}

\begin{tabular}{|c|c|c|}
\hline Name & Reference & Type \\
\hline Bai, Lama & Ethnologue & Unrecognized \\
\hline Baima & $\begin{array}{l}\text { Katia Chirkova (Qi Kajia 齐卡佳), } \\
\text { 'Baima Zangzu wei Dizu shuo zhiyi 白马 } \\
\text { 藏族为氏族说质疑', Zhongguo } \\
\text { Yuyanxue Jikan 中国语言学集刊, vol. 3, } \\
\text { 2008, pp. 161-174; Sun Hongkai 孙宏 } \\
\text { 开, Katia Chirkova (Qi Kajia 齐卡佳), } \\
\text { and Liu Guangkun 刘光坤, Baimayu } \\
\text { yanjiu 白马语研究, Minzu Chubanshe, } \\
\text { Beijing, 2008. Sun Hongkai 孙宏开, } \\
\text { 'Baimayu shi Zangyu de yige fangyan } \\
\text { huo tuhua ma? 白 } \square \text { 语是藏语的一个方言 } \\
\text { 或土话吗?, Yuyan kexue 语言科学, } \\
\text { vol. 1, 2003, pp. 65-75. }\end{array}$ & Unrecognized \\
\hline Basum $^{91}$ & $\begin{array}{l}\text { Qu Aitang 篗霷堂, dKon chog rgya } \\
\text { mtsho, bCo lnga and sKal bzang Ye shes, } \\
\text { 'Weizang fangyan de xin tuyu: Ji zuijin } \\
\text { faxian de Basonghua 卫藏方言的新土 } \\
\text { 语: 记最近发现的巴松话', Minzu } \\
\text { yuwen 民族语文, vol. 3, 1989, pp. 39- }\end{array}$ & Unrecognized \\
\hline
\end{tabular}

${ }^{91}$ Basum was described by Chinese scholars as a Tibetan dialect, but Tournadre (2005) re-analysed it as a non-Tibetic language that has been heavily influenced by the local Tibetic variety. 


\begin{tabular}{|c|c|c|}
\hline & $\begin{array}{l}\text { 61; Nicolas Tournadre, 'L'aire } \\
\text { linguistique tibétaine et ses divers } \\
\text { dialectes', Lalies vol. } 25,2005 \text {, pp. } 7 \text { - } \\
56 .\end{array}$ & \\
\hline Boga'er Luoba & Ethnologue & Extraterritorial \\
\hline Choyu & $\begin{array}{l}\text { Wang Tianxi 王天习, 'Queyuyu 却域语', } \\
\text { in Zangmianyu shiwuzhong 藏缅语十五 } \\
\text { 种, Dai Qingxia 戴庆厦, Huang Bufan 黄 } \\
\text { 布凡, Fu Ailan 傅爱兰, Rig 'dzin dBang } \\
\text { mo, and Liu Juhuang 刘菊黄 (eds), } \\
\text { Beijing Yanshan Chubanshe, Beijing, } \\
\text { 1990, pp. 46—63; Fuminobu Nishida 西 } \\
\text { 田文信, 'Tyuyugo no on-in taikei チュユ } \\
\text { 語の音韻体系', Tyuugoku kenkyuu 中国 } \\
\text { 研究, vol. 16, 2008, pp. 77—85. }\end{array}$ & Unrecognized \\
\hline Dakpa & Ethnologue & Extraterritorial \\
\hline Daohua & $\begin{array}{l}\text { Yixi Weisa Acuo 意西微萨・阿错 (Ye } \\
\text { shes 'Od gsal A tshogs), Daohua yanjiu } \\
\text { 倒话研究, Minzu Chubanshe, Beijing, } \\
2004 \text {. }\end{array}$ & Unrecognized \\
\hline Darang Deng & $\begin{array}{l}\text { Jiang Di 江荻, Li Daqin 李大勤 and Sun } \\
\text { Hongkai 孙宏开, Darangyu yanjiu 达让 } \\
\text { 语研究, Minzu Chubanshe, Beijing, } 2013 .\end{array}$ & Unrecognized \\
\hline Darmdo Minyag & $\begin{array}{l}\text { Takumi Ikeda, '200 example sentences in } \\
\text { the Mu-nya language (Tanggu dialect)' } \\
\text { ZINBUN, 40, 2007, pp. } 71-140 \text {; Dawa } \\
\text { Drolma and Hiroyuki Suzuki. } \\
\text { 'Preliminary report of the linguistic area } \\
\text { of Darmdo Minyag with a geolinguistic } \\
\text { description of "sun"', Studies in Asian } \\
\text { geolinguistics vol. 1, 2015, pp. 72-78. }\end{array}$ & Unrecognized \\
\hline Dza & $\begin{array}{l}\text { Sun Hongkai, 'On the Tibeto-Burman } \\
\text { languages of the Eastern Himalayan area } \\
\text { in China', Linguistics of Tibeto-Burman } \\
\text { area, vol. } 22,1999, \text { pp. } 61-72 .\end{array}$ & Unrecognized \\
\hline Geman Deng & $\begin{array}{l}\text { Li Daqin 李大勤, Gemanyu yanjiu 格曼 } \\
\text { 语研究, Minzu Chubanshe, Beijing, } 2002 .\end{array}$ & Unrecognized \\
\hline Geshitsa & $\begin{array}{l}\text { Hiroyuki Suzuki. 'Ergative marking in } \\
\text { Nyagrong-Minyag (Xinlong, Sichuan)', } \\
\text { Linguistics of the Tibeto-Burman area, } \\
\text { vol. } 35 \text {, no.1, 2012, pp. 35-48. }\end{array}$ & Unrecognized \\
\hline
\end{tabular}




\begin{tabular}{|c|c|c|}
\hline Guiqiong & $\begin{array}{l}\text { Song Lingli 宋伶俐, Guiqiongyu yanjiu } \\
\text { 贵琼语研究, Minzu Chubanshe, Beijing, } \\
\text { 2011; Jiang Li, A grammar of Guiqiong: } \\
\text { A language of Sichuan, Brill, Leiden, } \\
2015 \text {. }\end{array}$ & Unrecognized \\
\hline Japhug & $\begin{array}{l}\text { Guillaume Jacques, (Xiang Bolin 向柏霖 } \\
\text { ), Jiarongyu yanjiu 嘉线语研究, Minzu } \\
\text { Chubanshe, Beijing, 2008. Gates, Situ in } \\
\text { situ. }\end{array}$ & Unrecognized \\
\hline Kangjia & $\begin{array}{l}\text { Sechenchogtu [Siqinchaoketu 斯钦朝克 } \\
\text { 图], Kangjiayu yanjiu 康家语研究, } \\
\text { Shanghai, Yuandong Chubanshe, } \\
\text { Shanghai, } 1999 .\end{array}$ & Unrecognized \\
\hline Khroskyabs & $\begin{array}{l}\text { Huang Bufan 黄布凡, Lawurongyu yanjiu } \\
\text { 拉坞戎语研究, Minzu Chubanshe, } \\
\text { Beijing, 2007; Yin Weibin 尹蔚涁, } \\
\text { Yelong Lawurongyu yanjiu 业隆拉坞戎 } \\
\text { 语研究. Minzu Chubanshe, Beijing, } \\
\text { 2007; G.yu lha. 'Warming your hands } \\
\text { with moonlight: Lavrung Tibetan oral } \\
\text { traditions and culture', Asian highlands } \\
\text { perspectives, vol. 13, 2012, pp. 1-284, } \\
\text { https://www.repository.cam.ac.uk/handle/ } \\
\text { 1810/241079, accessed 12 December } \\
\text { 2015; Lai Yunfan, 'Causative } \\
\text { constructions in Wobzi Khroskyabs' } \\
\text { Paper presented at 14th International } \\
\text { Symposium on Chinese Languages and } \\
\text { Linguistics (Taipei), 2014, Online version } \\
\text { http://iscll-14.ling.sinica.edu.tw/files- } \\
\text { pdf/Papers/Session7/Lai.pdf, accessed on } \\
\text { 29 September 2015. }\end{array}$ & Unrecognized \\
\hline Laze & $\begin{array}{l}\text { Huang Bufan 黄布凡, 'Muli shuitianhua } \\
\text { yanjiu 木里水田话研究', Hanzangyu } \\
\text { xuebao 汉藏语学报 vol. 3, 2009, pp. } \\
\text { 30-55; Alexis Michaud, He Limin, and } \\
\text { Zhong Yaoping, 'Naxi (Naish)', } \\
\text { (Forthcoming in Rint Sybesma [chief } \\
\text { editor], Encyclopedia of Chinese } \\
\text { language and linguistics), } 2013 . \\
\text { https://halshs.archives- } \\
\text { ouvertes.fr/halshs- } \\
\text { 00793649/document, accessed } 12 \\
\text { December 2015. }\end{array}$ & Unrecognized \\
\hline Lizu & $\begin{array}{l}\text { Takumi Ikeda 池田巧, 'Seireki } 1853 \text { nen } \\
\text { ni kirokusareta Ryuzugo no goi 西暦 }\end{array}$ & Unrecognized \\
\hline
\end{tabular}




\begin{tabular}{|c|c|c|}
\hline & $\begin{array}{l}1853 \text { 年に記録されたリュズ語の語彙' } \\
\text { Toyo gakuho 東洋学報 } 85 \text { (2007), pp. } \\
\text { 653—672; Katia Chirkova, 2016. 'Lizu } \\
\text { (Ersu)' in Randy J. LaPolla and Graham } \\
\text { Thurgood (eds.) The Sino-Tibetan } \\
\text { Languages (Second Edition). New York: } \\
\text { Routledge, } 2016 \text { (in press). }\end{array}$ & \\
\hline Malimasa & $\begin{array}{l}\text { Li Zihe 李子鹤, 'Malimasahua gaikuang } \\
\text { 玛丽玛萨话概况', Hanzangyu xuebao 汉 } \\
\text { 藏语学报, vol. 7, 2013, pp. 91-117; } \\
\text { Suzuki, Hiroyuki. 'The vitality of Khams } \\
\text { Tibetan varieties in Weixi County', Asian } \\
\text { highland perspectives, forthcoming }\end{array}$ & Unrecognized \\
\hline Mongghul & $\begin{array}{l}\text { Burgel R. M. Faehndrich, Sketch } \\
\text { grammar of the Karlong variety of } \\
\text { Mongghul, and dialectal survey of } \\
\text { Mongghul, PhD thesis, University of } \\
\text { Hawai'i, } 2007 \text {. }\end{array}$ & $\begin{array}{l}\text { Enclave } \\
\text { (peripheral) }\end{array}$ \\
\hline Na Bengni & $\begin{array}{l}\text { Tianshin Jackson Sun, A historical- } \\
\text { comparative study of the Tani (Mirish) } \\
\text { branch in Tibeto-Burman, PhD thesis, } \\
\text { University of California, Berkeley, } 1993 .\end{array}$ & Extraterritorial \\
\hline nDrapa $^{92}$ & $\begin{array}{l}\text { Gong Qunhu 龚群虎. Zhabayu Yanjiu 扎 } \\
\text { 巴语研究, Minzu Chubanshe, Beijing, } \\
\text { 2007; Satoko Shirai, 'Effects of animacy } \\
\text { on existential sentences in nDrapa’, } \\
\text { Gengo kenkyu, vol. 134, 2008, pp. 1-22; } \\
\text { Satoko Shirai 白井聡子, Dapa-go ni } \\
\text { okeru siten hyoozi sisutemu no kenyuu ダ } \\
\text { パ語における視点表示システムの研究 } \\
\text {. Doctoral dissertation, Kyoto University, } \\
\text { 2006. }\end{array}$ & Unrecognized \\
\hline Wutun & $\begin{array}{l}\text { Juha Janhunen, Marja Peltomaa, Erika } \\
\text { Sandman, and Xiawu Dongzhou. Wutun, } \\
\text { Lincom Europa, München, } 2008 \text {. }\end{array}$ & Unrecognized \\
\hline Northern Qiang & Ethnologue & Unrecognized \\
\hline Nyagrong Minyag & $\begin{array}{l}\text { Bkra shis bzang po, 'May all good things } \\
\text { gather here: Life, religion, and marriage } \\
\text { in a Minyag Tibetan village', Asian } \\
\text { highlands perspectives, vol. } 14,2012 \text {, }\end{array}$ & Unrecognized \\
\hline
\end{tabular}

${ }^{92}$ When this language name is written as it is here, it directly designate one language. However, if it is written in Chinese characters, the situation is confusable because there are two languages designated in one manner of writing. 


\begin{tabular}{|c|c|c|}
\hline & $\begin{array}{l}\text { pp1-369; Suzuki, 'Ergative marking in } \\
\text { Nyagrong-Minyag'. }\end{array}$ & \\
\hline Oirat & $\begin{array}{l}\text { Jia Xiru. Mongolian language in Qinghai, } \\
\text { Qinghai Renmin Chubanshe, Xining, } \\
2006 . \text { Bum-Ochir Dulam, Respect and } \\
\text { power without resistance: Investigations } \\
\text { of interpersonal relations among the } \\
\text { Deed Mongols, PhD thesis, University of } \\
\text { Cambridge, } 2006 \text {. }\end{array}$ & Extraterritorial \\
\hline Prinmi & $\begin{array}{l}\text { Daudey, Gerdine Henriëtte. A grammar of } \\
\text { Wadu Pumi, PhD thesis, La Trobe } \\
\text { University, 2014; Ding, Picus Sizhi. A } \\
\text { grammar of Prinmi, Brill, Leiden, } 2014 .\end{array}$ & Unrecognized \\
\hline Puroik & $\begin{array}{l}\text { Li Daqin 李大勤. Sulongyu yanjiu 苏龙 } \\
\text { 语研究, Minzu Chubanshe, Beijing, } 2004 .\end{array}$ & Extraterritorial \\
\hline sTodsde & $\begin{array}{l}\text { Suzuki, 'Ergative marking in Nyagrong- } \\
\text { Minyag'. }\end{array}$ & Unrecognized \\
\hline Shimian Minyag & $\begin{array}{l}\text { Dawa Drolma and Suzuki, 'Preliminary } \\
\text { report of the linguistic area of Darmdo } \\
\text { Minyag' }\end{array}$ & Unrecognized \\
\hline Shixing & $\begin{array}{l}\text { Katia Chirkova and Chen Yiya. 'Xumi, } \\
\text { Part 1. Lower Xumi, the Variety of the } \\
\text { Lower and Middle Reaches of the Shuiluo } \\
\text { River', Journal of the international } \\
\text { phonetic association vol. 43, no. 3, 2013, } \\
\text { pp. 363-379; Katia Chirkova, Chen } \\
\text { Yiya, and Tanja Kocjančič Antolík. } \\
\text { 'Xumi, Part 2: Upper Xumi, the Variety } \\
\text { of the Upper Reaches of the Shuiluo } \\
\text { River', Journal of the international } \\
\text { phonetic association vol. 43, no. 3, 2013, } \\
\text { pp. 381-396; Sun Hongkai 孙宏开, Xu } \\
\text { Dan 徐丹, Liu Guangkun 刘光坤, and } \\
\text { Lurong Duoding 鲁茸多丁, Shixingyu } \\
\text { yanjiu 史兴语研究, Minzu Chubanshe, } \\
\text { Beijing, 2014. }\end{array}$ & Unrecognized \\
\hline Situ-rGyalrong & $\begin{array}{l}\text { Yasuhiko Nagano, 'Cogtse Gyalrong' in } \\
\text { Sino-Tibetan Languages, Graham } \\
\text { Thurgood and Randy LaPolla (eds), 2003, } \\
\text { pp. 469-489. Gates, Situ in situ. }\end{array}$ & Unrecognized \\
\hline $\begin{array}{l}\text { South-central } \\
\text { rGyalrong }\end{array}$ & $\begin{array}{l}\text { bTsan lha Ngag dbang Tshul khrims } \\
\text { (Marielle Prins and Yasuhiko Nagano } \\
\text { eds.) A lexicon of the rGyalrong bTsanlha } \\
\text { dialect: r ryalrong-Chinese-Tibetan- }\end{array}$ & Unrecognized \\
\hline
\end{tabular}




\begin{tabular}{|c|c|c|}
\hline & $\begin{array}{l}\text { English, National Museum of Ethnology, } \\
\text { Suita, 2009; Gates, Situ in situ. }\end{array}$ & \\
\hline Southern Qiang & Ethnologue & $\begin{array}{l}\text { Enclave } \\
\text { (peripheral) }\end{array}$ \\
\hline sTau & $\begin{array}{l}\text { Kun dga' dBang mo 根呷翁姆, Daofu } \\
\text { Zangzu de yuyan wenhua yanjiu 道孚藏 } \\
\text { 族的语言文化研究, PhD thesis, Xinan } \\
\text { Minzu Daxue, 2010; Suzuki, 'Ergative } \\
\text { marking in Nyagrong-Minyag'. }\end{array}$ & Unrecognized \\
\hline Thangmi & Ethnologue & Extraterritorial \\
\hline Tinani & Ethnologue & Extraterritorial \\
\hline Tongren $\mathrm{Tu}$ & $\begin{array}{l}\text { Robert Wayne Fried. A grammar of } \\
\text { Bao'an Tu, a Mongolic language of } \\
\text { northwest China, PhD thesis, University } \\
\text { of Buffalo, State University of New York, } \\
2010 \text {. }\end{array}$ & Unrecognized \\
\hline Tshangla & $\begin{array}{l}\text { Erik Andvik, A grammar of Tshangla. } \\
\text { Brill, Leiden, } 2010 .\end{array}$ & Extraterritorial \\
\hline Tshobdun & $\begin{array}{l}\text { Jackson Sun, 'Caodeng rGyalrong' in } \\
\text { Sino-Tibetan Languages, Graham } \\
\text { Thurgood and Randy LaPolla (eds), 2003, } \\
\text { pp. 490-502; Gates, Situ in situ. }\end{array}$ & Unrecognized \\
\hline Yidu Luoba & $\begin{array}{l}\text { Jiang Di 江荻, Yiduyu yanjiu 义都语研究 } \\
\text {, Minzu Chubanshe, Beijing, } 2005\end{array}$ & Extraterritorial \\
\hline Zakhring & Ethnologue & Extraterritorial \\
\hline $\mathrm{Zbu}$ & $\begin{array}{l}\text { Gong Xun. 'The personal agreement } \\
\text { system of Zbu Rgyalrong (Ngyaltsu } \\
\text { variety)', Transactions of the philological } \\
\text { society, vol. } 112 \text {, no.1, 2013, pp. } 44-60 \text {. } \\
\text { DOI: http://dx.doi.org/10.1111/1467-- } \\
\text { 968X.12007, accessed on 12 December } \\
\text { 2015; Gates, Situ in situ. }\end{array}$ & Unrecognized \\
\hline
\end{tabular}

\subsection{NTA}

\begin{tabular}{|lll|}
\hline \multicolumn{1}{|c|}{ Name } & \multicolumn{1}{c|}{ Reference } & Type \\
\hline Drung & $\begin{array}{l}\text { Randy J. LaPolla, 'Dulong' in Sino-Tibetan } \\
\text { languages, Thurgood and LaPolla (eds), } \\
\text { 2003, pp. 674—682; Qin and Suzuki, }\end{array}$ & Extraterritorial \\
\hline
\end{tabular}




\begin{tabular}{|c|c|c|}
\hline & $\begin{array}{l}\text { 'Chasing a cat from the Mekong to the } \\
\text { Salween'. }\end{array}$ & \\
\hline Doxu & $\begin{array}{l}\text { Huang Bufan 黄布凡 and Yin Weibin 尹蔚 } \\
\text { 涁. 'Duoxuyu gaikuang 多续语概况', } \\
\text { Hanzangyu xuebao 汉藏语学报, vol. 6, } \\
\text { 2012, pp. 58-87; Katia Chirkova, 'The } \\
\text { Duoxu language and the Ersu-Lizu-Duoxu } \\
\text { relationship', Linguistics of the Tibeto- } \\
\text { Burman area vol. 37, no.1, 2014, pp. 104- } \\
\text { 146. }\end{array}$ & Unrecognized \\
\hline Eastern Yugur & $\begin{array}{l}\text { Hans Nugteren, 'Shira Yugur' in Mongolic } \\
\text { languages, Juha Janhunen(ed), Routledge, } \\
\text { London, 2003, pp. } 265-285 .\end{array}$ & Enclave (peripheral) \\
\hline Ersu & $\begin{array}{l}\text { Zhang Sihong, A reference grammar of } \\
\text { Ersu: a Tibeto-Burman language of China, } \\
\text { PhD thesis, James Cook University, 2013, } \\
\text { http://eprints.jcu.edu.au/31252/, accessed on } \\
12 \text { December } 2015 .\end{array}$ & Unrecognized \\
\hline Lang'e & Ethnologue & Unrecognized \\
\hline Lipo & Ethnologue & Unrecognized \\
\hline Lisu & $\begin{array}{l}\text { Mu Yuzhang 木玉璋 and Sun Hongkai 孙 } \\
\text { 宏开. Lisuyu fangyan yanjiu 傈傈语方言研 } \\
\text { 究, Minzu Chubanshe, Beijing, } 2011 \text {. }\end{array}$ & Extraterritorial \\
\hline Mangghuer & $\begin{array}{l}\text { Keith W. Slater. A grammar of Mangghuer: } \\
\text { A Mongolic language of China's Qinghai- } \\
\text { Gansu sprachbund, Routledge, London, } \\
2003 \text {. }\end{array}$ & Unrecognized \\
\hline $\mathrm{Na} / \mathrm{Narua}$ & $\begin{array}{l}\text { Liberty A. Lidz, A descriptive grammar of } \\
\text { Yongning } \mathrm{Na} \text { (Mosuo), PhD thesis, } \\
\text { University of Texas, 2010; Guillaume } \\
\text { Jacques and Alexis Michaud, 'Approaching } \\
\text { the historical phonology of three highly } \\
\text { eroded Sino-Tibetan languages: Naxi, Na } \\
\text { and Laze' Diachronica, vol. } 28 \text {, no. } 4 \text {, } \\
\text { 2011, pp. } 468 \text {-498. }\end{array}$ & Unrecognized \\
\hline Namuyi & $\begin{array}{l}\text { Libu Lakhi, Brook Hefright, and Kevin } \\
\text { Stuart, 'The Namuyi: Linguistic and } \\
\text { cultural features', Asian folklore studies, } \\
\text { vol. 66, 2007, pp. 233-253. }\end{array}$ & Unrecognized \\
\hline Naxi & Michaud et al, 'Naxi (Naish)'. & Extraterritorial \\
\hline Nuosu & Chen Kang 陈康. Yiyu fangyan yanjiu 彝语 & Extraterritorial \\
\hline
\end{tabular}




\begin{tabular}{|c|c|c|}
\hline & $\begin{array}{l}\text { 方言研究, Zhongyang Minzu Daxue } \\
\text { Chubanshe, Beijing, } 2010 .\end{array}$ & \\
\hline Pumi, south & $\begin{array}{l}\text { Jiang Ying 蒋颖, ‘Dayang pumiyu gaikuang } \\
\text { 大羊普米 } \square \text { 研究', Hanzangyu xuebao 汉藏 } \\
\text { 语学报, vol. 7, 2013, pp. 54-90. }\end{array}$ & Extraterritorial \\
\hline Salar & $\begin{array}{l}\text { Arienne M. Dwyer, Salar: A study in Inner } \\
\text { Asian language contact processes, Otto } \\
\text { Harrassowitz Verlag, Wiesbaden, } 2007 .\end{array}$ & Enclave \\
\hline Talu & $\begin{array}{l}\text { Zhou Decai 周德才, Taliuhua yanjiu 他留 } \\
\text { 话研究, Yunnan Minzu Chubanshe, } \\
\text { Kunming, 2004. }\end{array}$ & Unrecognized \\
\hline Tanglang & $\begin{array}{l}\text { Gai Xingzhi 盖兴之 and Wang Yan 王艳. } \\
\text { ‘Tanglangyu yuyin qianshuo 堂郎语语音浅 } \\
\text { 说', Cahiers de linguistique Asie orientale, } \\
\text { vol. 42, no. 2, 2013, pp. 163-177. }\end{array}$ & Unrecognized \\
\hline Western Yugur & $\begin{array}{l}\text { Martina Roos, The Western Yugur (Yellow } \\
\text { Uygur) language: Grammar, texts, } \\
\text { vocabulary, PhD thesis, University of } \\
\text { Leiden, } 2000 .\end{array}$ & Enclave (peripheral) \\
\hline
\end{tabular}




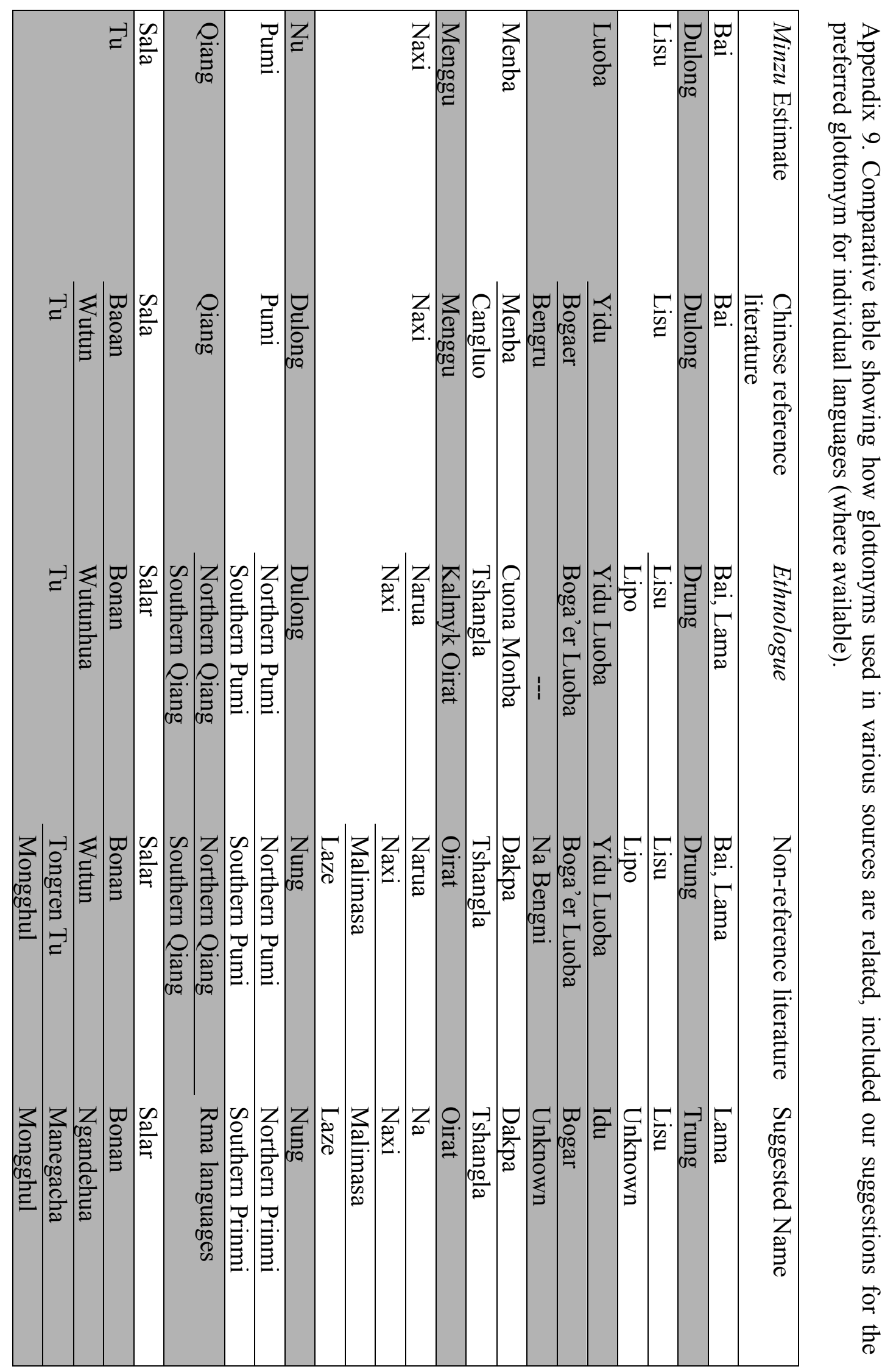




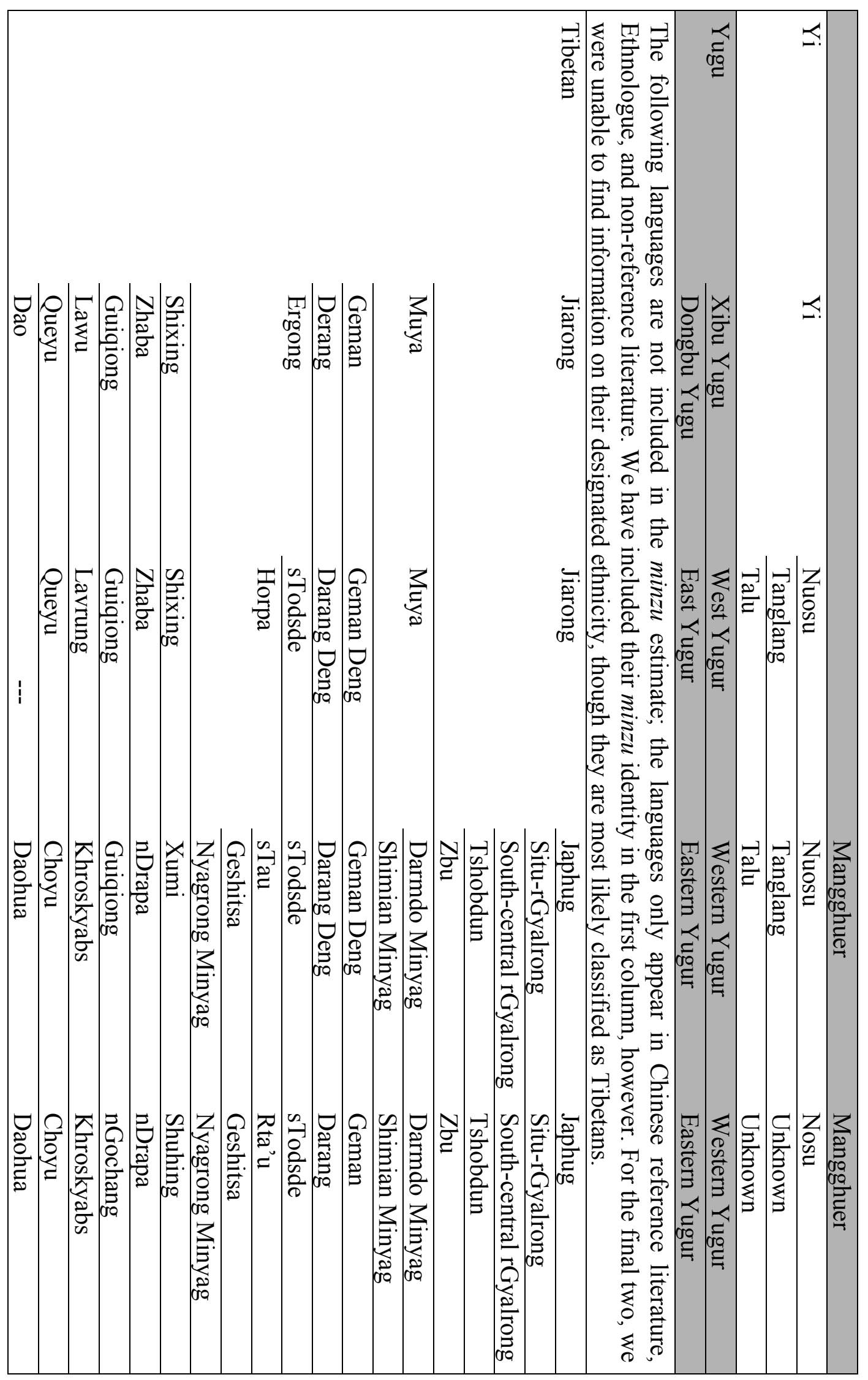




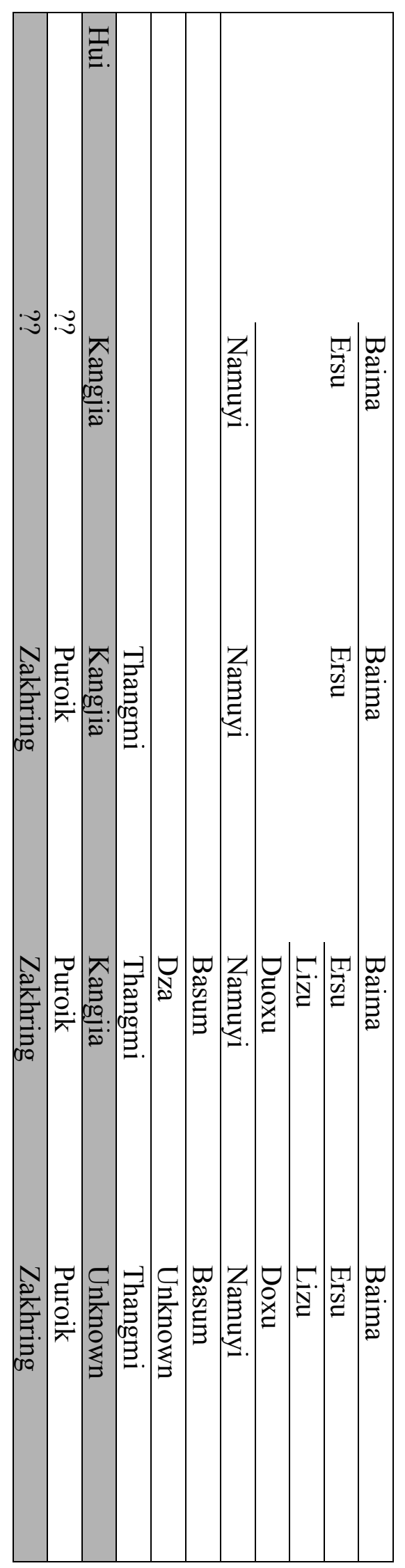

